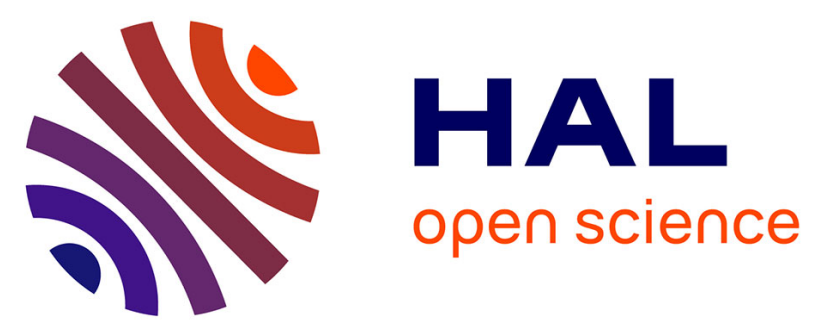

\title{
A combined operando synchrotron X-ray absorption spectroscopy and first-principles density functional theory study to unravel the vanadium reedox paradox in the Na3V2(PO4)2F3-Na3V2(PO4)2FO2 compositions
} Long H. B. Nguyen, Antonella Iadecola, Stéphanie Belin, Jacob Olchowka, Christian Masquelier, Dany Carlier, Laurence Croguennec

\section{To cite this version:}

Long H. B. Nguyen, Antonella Iadecola, Stéphanie Belin, Jacob Olchowka, Christian Masquelier, et al.. A combined operando synchrotron X-ray absorption spectroscopy and first-principles density functional theory study to unravel the vanadium reedox paradox in the Na3V2(PO4)2F3Na3V2(PO4)2FO2 compositions. Journal of Physical Chemistry C, 2020, 124 (43), pp.23511-23522. 10.1021/acs.jpcc.0c06967 . hal-02978467

\section{HAL Id: hal-02978467 \\ https://hal.science/hal-02978467}

Submitted on 26 Oct 2020

HAL is a multi-disciplinary open access archive for the deposit and dissemination of scientific research documents, whether they are published or not. The documents may come from teaching and research institutions in France or abroad, or from public or private research centers.
L'archive ouverte pluridisciplinaire HAL, est destinée au dépôt et à la diffusion de documents scientifiques de niveau recherche, publiés ou non, émanant des établissements d'enseignement et de recherche français ou étrangers, des laboratoires publics ou privés. 


\title{
A Combined Operando Synchrotron X-ray Absorption Spectroscopy and First-Principles Density Functional Theory Study to Unravel the Vanadium Redox Paradox in the $\mathrm{Na}_{3} \mathrm{~V}_{2}\left(\mathrm{PO}_{4}\right)_{2} \mathrm{~F}_{3}-\mathrm{Na}_{3} \mathrm{~V}_{2}\left(\mathrm{PO}_{4}\right)_{2} \mathrm{FO}_{2} \mathrm{Com}-$ positions
}

\author{
Long H. B. Nguyen, ${ }^{\dagger, \dagger}, \S$ Antonella Iadecola, ${ }^{\S}$ Stéphanie Belin, ${ }^{* * *}$ Jacob Olchowka, ${ }^{\dagger}, \S$ Christian \\ Masquelier, ${ }^{\star, \S, \|}$ Dany Carlier, ${ }^{\dagger, \S, \|}$ Laurence Croguennec $*, \dagger, \S, \|$ \\ $\dagger$ CNRS, Univ. Bordeaux, Bordeaux INP, ICMCB, UMR CNRS 5026, F-33600, Pessac, France. \\ \$ Laboratoire de Réactivité et Chimie des Solides, UMR CNRS 7314, Université de Picardie Jules Verne, F-80039 Amiens \\ Cedex 1, France.
}

** SOLEIL Synchrotron, F-91192 Gif-sur-Yvette, France.

$\S$ RS2E, Réseau Français sur le Stockage Electrochimique de l'Energie, FR CNRS 3459, F-80039 Amiens Cedex 1, France.

\| ALISTORE-ERI European Research Institute, FR CNRS 3104, Amiens, F-80039 Cedex 1, France.

\begin{abstract}
The redox processes involved in the $\mathrm{Na}^{+}$deintercalation from $\mathrm{Na}_{3} \mathrm{~V}_{2}\left(\mathrm{PO}_{4}\right)_{2} \mathrm{~F}_{3}, \mathrm{Na}_{3} \mathrm{~V}_{2}\left(\mathrm{PO}_{4}\right)_{2} \mathrm{~F}_{2} \mathrm{O}$ and $\mathrm{Na}_{3} \mathrm{~V}_{2}\left(\mathrm{PO}_{4}\right)_{2} \mathrm{~F}_{1.5} \mathrm{O}_{1.5}$ are investigated operando by synchrotron X-ray absorption spectroscopy at the Vanadium K-edge. A continuous evolution in the preedge and edge regions is observed for the three compositions, which is in good agreement with a progressive oxidation of vanadium. In the oxygen-substituted compositions, $\mathrm{Na}_{3} \mathrm{~V}_{2}\left(\mathrm{PO}_{4}\right)_{2} \mathrm{~F}_{2} \mathrm{O}$ and $\mathrm{Na}_{3} \mathrm{~V}_{2}\left(\mathrm{PO}_{4}\right)_{2} \mathrm{~F}_{1.5} \mathrm{O}_{1.5}$, the $\mathrm{F}-\mathrm{V}^{3+} \mathrm{O}_{4}-\mathrm{F}$ and $\mathrm{F}-\mathrm{V}^{4+} \mathrm{O}_{4}=\mathrm{O}$ redox centers coexist and can be simultaneously activated thanks to the reverse inductive effect promoted by the presence of highly covalent vanadyl bonds on $\mathrm{V}^{4+}$ sites. Principal component analysis of the dataset collected operando for the three compositions is performed. It reveals that three independent spectra, corresponding to different charge orderings on vanadium sites at different states of charge, are required to describe these three systems. The extended X-ray absorption fine structure analysis of the principal components is performed in order to gain insightful information on the evolution of the vanadium local environment upon cycling. By the use of first-principles density functional theory calculations, we demonstrate that the potential step observed in all $\mathrm{Na}_{2} \mathrm{~V}_{2}\left(\mathrm{PO}_{4}\right)_{2} \mathrm{~F}_{3-y} \mathrm{O}_{y}$ compositions is related to a charge ordering on vanadium sites with a preferential oxidation of vanadium ions in the same bioctahedra.
\end{abstract}

\section{- INTRODUCTION}

Sodium-ion batteries (SIBs) have recently been introduced and developed as a future alternate to the conventional lithiumion batteries (LIBs). In a typical SIB, the positive electrode material plays a crucial role in determining the overall performance of the full battery. ${ }^{1-4}$ Several layered transition metal oxides, polyanionic compounds and Prussian blue analogues have been identified as active materials for positive electrode for SIBs. ${ }^{5-13}$ Among all these materials, sodium vanadium oxy-fluorophosphates, $\mathrm{Na}_{3} \mathrm{~V}_{2}\left(\mathrm{PO}_{4}\right)_{2} \mathrm{~F}_{3-y} \mathrm{O}_{y}(0 \leq y \leq 2)$, are among the most promising ones thanks to their high operating voltages $(\sim 3.9 \mathrm{~V}$ $\mathrm{vs} \mathrm{Na}^{+} / \mathrm{Na}$ ), their high theoretical gravimetric capacities associated to the reversible extraction/insertion of two $\mathrm{Na}^{+}$ions per formula unit, and their high stability upon long-term cycling. ${ }^{13-}$ 18

All $\mathrm{Na}_{3} \mathrm{~V}_{2}\left(\mathrm{PO}_{4}\right)_{2} \mathrm{~F}_{3-y} \mathrm{O}_{y}(0<y \leq 2)$ compositions can be considered as oxygen-substituted derivatives of $\mathrm{Na}_{3} \mathrm{~V}_{2}\left(\mathrm{PO}_{4}\right)_{2} \mathrm{~F}_{3}$. The crystal structure of $\mathrm{Na}_{3} \mathrm{~V}_{2}\left(\mathrm{PO}_{4}\right)_{2} \mathrm{~F}_{3}$ is built from a three-dimensional interconnection of $\mathrm{V}_{2} \mathrm{O}_{8} \mathrm{~F}_{3}$ bioctahedral units and $\mathrm{PO}_{4}$ groups. Each $\mathrm{V}_{2} \mathrm{O}_{8} \mathrm{~F}_{3}$ bioctahedron consists of two sub-octahedra containing $\mathrm{V}^{3+}$ centers coordinated by four oxygen atoms in an equatorial plane and two fluorine atoms on the axial positions. These two octahedral sub-units are bridged together through a common fluorine atom, and the relatively mobile $\mathrm{Na}^{+}$ions occupy the empty space in the structure locating in the crystallographic planes at $z=0$ and $z=1 / 2$. (Figure 1a). ${ }^{19,20}$
The two terminal fluorine atoms in the $\mathrm{V}_{2} \mathrm{O}_{8} \mathrm{~F}_{3}$ bioctahedral groups can be partially or fully replaced by $\mathrm{O}^{2-}$ ions, thus leading to the formation of $\mathrm{Na}_{3} \mathrm{~V}_{2}\left(\mathrm{PO}_{4}\right)_{2} \mathrm{~F}_{3-y} \mathrm{O}_{y}(0 \leq y \leq 2)$ compositions, which can also be written as $\mathrm{Na}_{3} \mathrm{~V}_{2-y}(\mathrm{VO})_{y}\left(\mathrm{PO}_{4}\right)_{2} \mathrm{~F}_{3-y}{ }^{13,16-}$

${ }^{18}$ In order to maintain the charge neutrality in these oxygen substituted compositions, the vanadium ion bonded to the terminal $\mathrm{O}^{2-}$ is oxidized into $\mathrm{V}^{4+}$ together with the formation of the highly covalent vanadyl bond $\left(\mathrm{V}^{4+}=\mathrm{O}\right)$ (Figure $\left.1 \mathrm{~b}\right)$. The presence of these vanadyl bonds has a significant impact on the crystal structure, the electrochemical performance as well as the ionic transport properties of the oxygen-substituted phases. ${ }^{13,16-18,21,22}$ Oxygen substitution for fluorine helps to improve the $\mathrm{Na}^{+}$diffusion processes, modifies the desodiation mechanism, and enhances the stability of the phase especially at high voltage in its highly deintercalated state. Furthermore, experimental observations have pointed out that the desodiation voltage decreases gradually when the oxygen substitution for fluorine occurs in these compositions. ${ }^{13,16,18}$ A similar phenomenon has also been observed in the $\mathrm{LiVPO}_{4} \mathrm{~F}_{1-y} \mathrm{O}_{y}(0 \leq y \leq 1)$ material family ${ }^{23,24}$, and the lowering of the delithiation voltage due to the formation of highly covalent $\mathrm{V}^{4+}=\mathrm{O}$ bonds in $\mathrm{LiVPO}_{4} \mathrm{~F}_{1-y} \mathrm{O}_{y}$ was attributed to the so-called "reversed inductive effect" (Figure S1). By the use of operando X-ray absorption spectroscopy (XAS) at V Kedge, our group has demonstrated that all $\mathrm{O}_{5} \mathrm{~V}^{4+}=\mathrm{O}$ redox centers in $\mathrm{LiVPO}_{4} \mathrm{~F}_{1-y} \mathrm{O}_{y}(0<y<1)$ would be oxidized before the activation of $\mathrm{V}^{3+} \mathrm{O}_{4} \mathrm{~F}_{2}$. Furthermore, the activation of the $\left\{\mathrm{O}_{5} \mathrm{~V}^{5+}=\mathrm{O}\right\}^{3+} /\left\{\mathrm{O}_{5} \mathrm{~V}^{4+}=\mathrm{O}\right\}^{2+}$ redox couple in $\mathrm{LiVPO}_{4} \mathrm{~F}_{1-y} \mathrm{O}_{y}$ 
$(0<y<1)$ occurs through a solid solution mechanism whereas the oxidation of $\mathrm{V}^{3+} \mathrm{O}_{4} \mathrm{~F}_{2}$ into $\mathrm{V}^{4+} \mathrm{O}_{4} \mathrm{~F}_{2}$ is accompanied by a biphasic reaction. $^{23}$

(a)

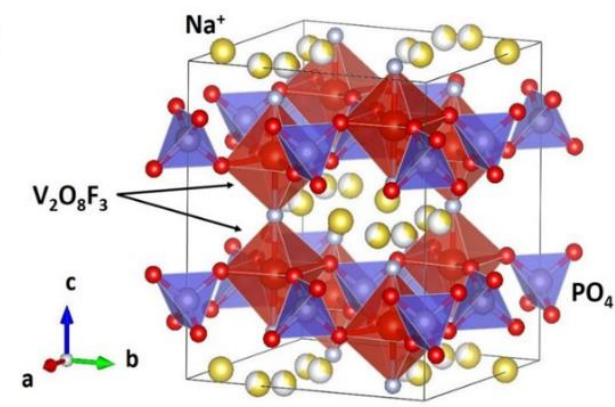

(b)

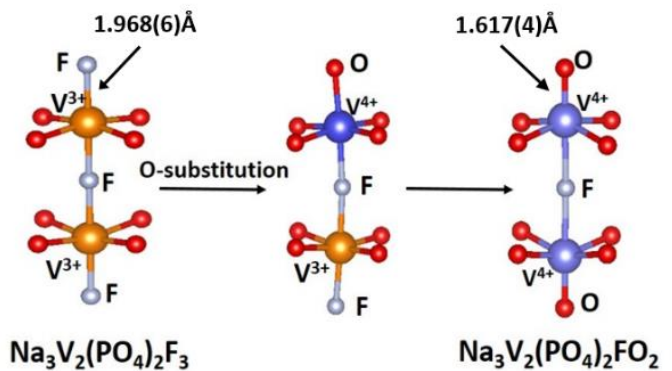

Figure 1. (a) $3 \mathrm{D}$ crystal structure of $\mathrm{Na}_{3} \mathrm{~V}_{2}\left(\mathrm{PO}_{4}\right)_{2} \mathrm{~F}_{3}$. The bioctahedral units $\mathrm{V}_{2} \mathrm{O}_{8} \mathrm{~F}_{3}$ and tetrahedral $\mathrm{PO}_{4}$ groups are shown as red and blue polyhedra, respectively. The $\mathrm{Na}^{+}$ions, represented by yellow spheres, occupy the empty space in the structure locating in the crystallographic planes at $z=0$ and $z=1 / 2$, the partial filling of the yellow spheres highlighting the occupancy of the sites. (b) Schematic illustration of the oxygen substitution on the terminal fluorine positions of the bi-octahedron $\mathrm{V}_{2} \mathrm{O}_{8} \mathrm{~F}_{3}$ leading to the formation of $\mathrm{Na}_{3} \mathrm{~V}^{3+}{ }_{2-y} \mathrm{~V}^{4+}{ }_{y}\left(\mathrm{PO}_{4}\right)_{2} \mathrm{~F}_{3-y} \mathrm{O}_{y}$ phases with the presence of the highly covalent vanadyl bonds $\left(\mathrm{V}^{4+}=\mathrm{O}\right)$.

Operando synchrotron XAS at V K-edge during the $\mathrm{Na}^{+}$ extraction from $\mathrm{Na}_{3} \mathrm{~V}_{2}\left(\mathrm{PO}_{4}\right)_{2} \mathrm{~F}_{3}$ recorded in fluorescence mode has recently been reported by our group. ${ }^{25} \mathrm{We}$ have demonstrated that the desodiation from $\mathrm{Na}_{3} \mathrm{~V}_{2}\left(\mathrm{PO}_{4}\right)_{2} \mathrm{~F}_{3}$ occurred through two successive steps: $(i)$ the $\mathrm{F}-\mathrm{V}^{3+} \mathrm{O}_{4}-\mathrm{F}-\mathrm{V}^{3+} \mathrm{O}_{4}-\mathrm{F}$ bioctahedral units in the initial state were gradually oxidized into $\mathrm{F}-\mathrm{V}^{3+} \mathrm{O}_{4}-\mathrm{F}-\mathrm{V}^{4+} \mathrm{O}_{4}-\mathrm{F}$ upon the electrochemical extraction of the first $\mathrm{Na}^{+}$and (ii) the intermediate $\mathrm{F}-\mathrm{V}^{3+} \mathrm{O}_{4}-\mathrm{F}-\mathrm{V}^{4+} \mathrm{O}_{4}-\mathrm{F}$ units would evolve gradually into $\mathrm{F}-\mathrm{V}^{3+} \mathrm{O}_{4}-\mathrm{F}-\mathrm{V}^{5+} \mathrm{O}_{4}-\mathrm{F}$ upon the removal of the second $\mathrm{Na}^{+}$ion. ${ }^{25}$ We also hypothesized that the formation of $\mathrm{F}-\mathrm{V}^{3+} \mathrm{O}_{4}-\mathrm{F}-\mathrm{V}^{5+} \mathrm{O}_{4}-\mathrm{F}$ can occur: (i) through a direct oxidation of $\mathrm{F}-\mathrm{V}^{3+} \mathrm{O}_{4}-\mathrm{F}-\mathrm{V}^{4+} \mathrm{O}_{4}-\mathrm{F}$, or (ii) through a transient state, $\mathrm{F}-\mathrm{V}^{4+} \mathrm{O}_{4}-\mathrm{F}-\mathrm{V}^{4+} \mathrm{O}_{4}-\mathrm{F}$, followed by a disproportionation of two $\mathrm{V}^{4+}$ ions present in the same bioctahedral unit. Even though the mechanism of the second step was unclear, the presence of $\mathrm{V}^{5+}$ ions in $\mathrm{NaV}_{2}\left(\mathrm{PO}_{4}\right)_{2} \mathrm{~F}_{3}$ was confirmed by ${ }^{51} \mathrm{~V}$ solidstate nuclear magnetic resonance (ss-NMR) spectroscopy. ${ }^{25}$ Nonetheless, our previous study focused only on the changes in vanadium's oxidation states upon electrochemical cycling without giving any information on the vanadium's local structure upon $\mathrm{Na}^{+}$extraction.

In oxygen-substituted $\mathrm{Na}_{3} \mathrm{~V}_{2}\left(\mathrm{PO}_{4}\right)_{2} \mathrm{~F}_{3-y} \mathrm{O}_{y}(0<y<2)$ compositions, the redox mechanism would be much more complex. The formation of vanadyl bonds leads to the coexistence of two different vanadium redox centers: $\mathrm{F}-\mathrm{V}^{3+} \mathrm{O}_{4}-\mathrm{F}$ and $\mathrm{F}-\mathrm{V}^{4+} \mathrm{O}_{4}=\mathrm{O}$, which are hereafter denoted as $\mathrm{V}^{3+}-\mathrm{F}$ and $\mathrm{V}^{4+}=\mathrm{O}$, respectively.
Many recent studies have pointed out that the presence of $\mathrm{V}^{4+}=\mathrm{O}$ redox centers helps to shift down the $\mathrm{Na}^{+}$-extraction voltages in $\mathrm{Na}_{3} \mathrm{~V}_{2}\left(\mathrm{PO}_{4}\right)_{2} \mathrm{~F}_{3-y} \mathrm{O}_{y}(0<y \leq 2)$ as compared to $\mathrm{Na}_{3} \mathrm{~V}_{2}\left(\mathrm{PO}_{4}\right)_{2} \mathrm{~F}_{3} \cdot{ }^{13,18,26}$ By analyzing the ${ }^{23} \mathrm{Na}$ ss-NMR and electron paramagnetic resonant (EPR) spectra recorded ex situ on $\mathrm{Na}_{x} \mathrm{~V}_{2}\left(\mathrm{PO}_{4}\right)_{2} \mathrm{~F}_{1.4} \mathrm{O}_{1.6}(1 \leq x \leq 3)$ samples recovered at different states of charge of the battery, Li et al. reported that $\mathrm{V}^{4+}=\mathrm{O}$ redox centers were preferentially oxidized in the potential range of $2.0-3.9 \mathrm{~V}$ vs $\mathrm{Na}^{+} / \mathrm{Na}$ while in the higher-voltage region $(3.9-4.8 \mathrm{~V}), \mathrm{V}^{3+}-\mathrm{F}$ and $\mathrm{V}^{4+}=\mathrm{O}$ were simultaneously activated. ${ }^{27}$ Nevertheless, there was no information on the evolution of vanadium's local environments upon cycling, e.g. their bond lengths, reported in this previous study.

In this new study, we compare the redox processes as well as the changes in vanadium's local environment involved in the desodiation process of the three representatives belonging to the $\mathrm{Na}_{3} \mathrm{~V}_{2}\left(\mathrm{PO}_{4}\right)_{2} \mathrm{~F}_{3-y} \mathrm{O}_{y}(0 \leq y \leq 2)$ series, including $\mathrm{Na}_{3} \mathrm{~V}_{2}\left(\mathrm{PO}_{4}\right)_{2} \mathrm{~F}_{3}$ (with $\mathrm{F}-\mathrm{V}^{3+} \mathrm{O}_{4}-\mathrm{F}$ environments only), $\mathrm{Na}_{3} \mathrm{~V}_{2}\left(\mathrm{PO}_{4}\right)_{2} \mathrm{~F}_{2} \mathrm{O}$ (mixed valence with $\mathrm{F}-\mathrm{V}^{3+} \mathrm{O}_{4}-\mathrm{F}$ and $\mathrm{F}-\mathrm{V}^{4+} \mathrm{O}_{4}=\mathrm{O}$ environments in the $1 / 1$ ratio) and $\mathrm{Na}_{3} \mathrm{~V}_{2}\left(\mathrm{PO}_{4}\right)_{2} \mathrm{~F}_{1.5} \mathrm{O}_{1.5}$ (mixed valence with $\mathrm{F}-\mathrm{V}^{3+} \mathrm{O}_{4}-\mathrm{F}$ and $\mathrm{F}-\mathrm{V}^{4+} \mathrm{O}_{4}=\mathrm{O}$ environments in the $1 / 3$ ratio) by operando synchrotron XAS. The obtained dataset is analyzed by a chemometric approach combined with a theoretical study from first-principles density functional theory (DFT) calculations in order to obtain an insightful understanding on the redox mechanism of vanadium ions in these oxy-fluorophosphates.

\section{- METHODS}

Sample Preparations. $\mathrm{Na}_{3} \mathrm{~V}_{2}\left(\mathrm{PO}_{4}\right)_{2} \mathrm{~F}_{3}, \mathrm{Na}_{3} \mathrm{~V}_{2}\left(\mathrm{PO}_{4}\right)_{2} \mathrm{~F}_{2} \mathrm{O}$, and $\mathrm{Na}_{3} \mathrm{~V}_{2}\left(\mathrm{PO}_{4}\right)_{2} \mathrm{~F}_{1.5} \mathrm{O}_{1.5}$ samples were obtained through a solidstate synthesis approach described elsewhere. ${ }^{13,16,18}$ The X-ray diffraction pattern analysis and the chemical composition have been reported for each sample in Ref ${ }^{18}$.

Synchrotron X-ray Absorption Spectroscopy was performed at the Vanadium K-edge energy in transmission mode at the ROCK beamline of the SOLEIL synchrotron facility (Saint-Aubin, France). ${ }^{28}$ In order to perform operando XAS measurements, the electroactive material was homogeneously mixed with carbon black and polytetrafluoroethylene (PTFE) in the ratio of 30/60/10 (by wt.\%) then pressed in a $13 \mathrm{~mm}$ pellet die under 10 tons to form self-standing films of $\sim 300 \mu \mathrm{m}$ in thickness. ${ }^{29}$ Three different half-cells using $\mathrm{Na}_{3} \mathrm{~V}_{2}\left(\mathrm{PO}_{4}\right)_{2} \mathrm{~F}_{3}$, $\mathrm{Na}_{3} \mathrm{~V}_{2}\left(\mathrm{PO}_{4}\right)_{2} \mathrm{~F}_{2} \mathrm{O}$ and $\mathrm{Na}_{3} \mathrm{~V}_{2}\left(\mathrm{PO}_{4}\right)_{2} \mathrm{~F}_{1.5} \mathrm{O}_{1.5}$ as positive electrodes were prepared for the operando XAS experiments. In order to avoid the strong absorption which might occur due to the high $\mathrm{X}$-ray absorption coefficient of sodium, a hole was made in the $\mathrm{Na}$ negative electrodes. The $\mathrm{Na} / / \mathrm{Na}_{3} \mathrm{~V}_{2}\left(\mathrm{PO}_{4}\right)_{2} \mathrm{~F}_{2} \mathrm{O}$ and $\mathrm{Na} / / \mathrm{Na}_{3} \mathrm{~V}_{2}\left(\mathrm{PO}_{4}\right)_{2} \mathrm{~F}_{1.5} \mathrm{O}_{1.5}$ half-cells were cycled at $\mathrm{C} / 10$ cycling rate (per $\mathrm{Na}^{+}$) from $2.5 \mathrm{~V}$ up to $4.5 \mathrm{~V}$ vs $\mathrm{Na}^{+} / \mathrm{Na}$ while the $\mathrm{Na} / / \mathrm{Na}_{3} \mathrm{~V}_{2}\left(\mathrm{PO}_{4}\right)_{2} \mathrm{~F}_{3}$ half-cell was cycled at $\mathrm{C} / 5$ cycling rate (per $\mathrm{Na}^{+}$). The $\mathrm{Na}_{3} \mathrm{~V}_{2}\left(\mathrm{PO}_{4}\right)_{2} \mathrm{~F}_{3}$ powder was carbon-coated allowing the application of a high current without inducing significant polarization. Thanks to an automatic sample changer, these $o p$ erando cells were measured in parallel with an acquisition time of 6 mins (690 scans/spectrum) and the time interval between two successive spectra was 12 mins. The monochromatization was ensured using the channel-cut Si (111) QuickExafs monochromator ${ }^{30}$ and the beam size was $1.5 \mathrm{~mm} \times 0.45 \mathrm{~mm}$ (horizontal $\times$ vertical). Three detectors in series allowed to measure during all the experiments a Vanadium metal foil which was used as reference to calibrate the energy. The energy calibration 
and normalization were done using graphical interfaces available on the ROCK beamline. ${ }^{31}$ The ex situ samples $\left(\mathrm{V}^{3+} \mathrm{PO}_{4}\right.$, $\mathrm{LiV}^{4+} \mathrm{OPO}_{4}, \mathrm{Na}_{3} \mathrm{~V}^{4+}{ }_{2}\left(\mathrm{PO}_{4}\right)_{2} \mathrm{FO}_{2}$, and $\left.\mathrm{V}^{5+} \mathrm{OPO}_{4}\right)$ were used as references to determine the oxidation states of vanadium species. The operando XAS dataset was used as input for the principal component analysis (PCA) in order to determine the number of independent components and their corresponding concentration profile. The expected XAS spectrum of these principal components was thus reconstructed using multivariate curve resolution-alternating least-squares (MCR-ALS) analysis. ${ }^{32}$ The details of the PCA and MCR-ALS analyses have been described elsewhere. ${ }^{25,33-39}$ The extended X-ray absorption fine structure (EXAFS) analysis was performed on the reconstructed spectra using the Demeter package. ${ }^{40}$ Fourier transforms of the $k^{2}$ weighted EXAFS oscillations were carried out in the $k$ range of 2.6-11.7 $\AA^{-1}$. Fitting was performed in the $\mathrm{R}$ range of $1.0-2.2$ $\AA$. EXAFS amplitudes and phase shifts were calculated by FEFF7. Except for the radial distance $\left(\mathrm{R}_{i}\right)$, the Debye-Waller factor $\left(\sigma_{i}^{2}\right)$ and the energy shift $\left(E^{0}\right)$, all the other parameters were kept constant during the fit: the coordination number of each vanadium $\left(\mathrm{N}=6\right.$, as $\mathrm{O}^{2-}$ and $\mathrm{F}^{-}$are similar $\mathrm{X}$-ray scatterers), and the attenuation factor $\left(S_{0}^{2}=1\right)$. Due to the limited number of independent parameters that can be refined at the same time, one Debye-Waller factor is used for all F/O ligands surrounding the vanadium center despite the difference in the nature and the covalency of the respective chemical bonds.

Density Functional Theory Calculations. First-principles calculations were performed within the DFT framework, and the calculations using the projector-augmented wave (PAW) method ${ }^{41,42}$ were computed with the Vienna ab initio simulation package (VASP) code ${ }^{41,43-46}$. The energy minimization and electronic density on each atom were calculated using the Hubbard- $U$ corrected PBE ${ }^{47}$ exchange correlation functional with an effective $U$ value of $3.1 \mathrm{eV}$ applied on the $d$ states of vanadium, based on the reported optimization of the formation enthalpies of vanadium-containing compounds. ${ }^{48} \mathrm{~A}$ pseudopotential of $600 \mathrm{eV}$ and an automatic $k$-mesh of $2 \times 2 \times 2$ were used for all calculations, except in the case of $\mathrm{NaV}_{2}\left(\mathrm{PO}_{4}\right)_{2} \mathrm{~F}_{3}$ supercell, where the $2 \times 2 \times 1 \quad k$-mesh was employed. The structure optimization, the stability and the $\mathrm{Na}^{+}$distribution for all the compositions in the $\mathrm{Na}_{4} \mathrm{~V}_{2}\left(\mathrm{PO}_{4}\right)_{2} \mathrm{~F}_{3}-\mathrm{V}_{2}\left(\mathrm{PO}_{4}\right)_{2} \mathrm{~F}_{3}$ system had earlier been reported by Ceder's group, ${ }^{49}$ and the $\mathrm{Na}^{+}$orderings reported in this previous study were used as input models for $\mathrm{Na}_{2} \mathrm{~V}_{2}\left(\mathrm{PO}_{4}\right)_{2} \mathrm{~F}_{3}$ and $\mathrm{NaV}_{2}\left(\mathrm{PO}_{4}\right)_{2} \mathrm{~F}_{3}$. In the case of $\mathrm{Na}_{3} \mathrm{~V}_{2}\left(\mathrm{PO}_{4}\right)_{2} \mathrm{~F}_{2} \mathrm{O}$, our group had earlier reported that there were different ways to distribute the $\mathrm{F}^{-}$and $\mathrm{O}^{2-}$ ions on the terminal positions of the bi-octahedral units and all these models possessed similar stability ${ }^{50}$; nonetheless, the $\mathrm{Na}^{+}$distribution in the desodiated compositions, particularly $\mathrm{Na}_{2} \mathrm{~V}_{2}\left(\mathrm{PO}_{4}\right)_{2} \mathrm{~F}_{2} \mathrm{O}$ and $\mathrm{NaV}_{2}\left(\mathrm{PO}_{4}\right)_{2} \mathrm{~F}_{2} \mathrm{O}$, has never been examined by DFT calculations. In order to create the input models for $\mathrm{Na}_{2} \mathrm{~V}_{2}\left(\mathrm{PO}_{4}\right)_{2} \mathrm{~F}_{2} \mathrm{O}$ and $\mathrm{NaV}_{2}\left(\mathrm{PO}_{4}\right)_{2} \mathrm{~F}_{2} \mathrm{O}$, we assumed that the $\mathrm{Na}^{+}$orderings in these phases would be similar to those reported for their counterparts, $\mathrm{Na}_{2} \mathrm{~V}_{2}\left(\mathrm{PO}_{4}\right)_{2} \mathrm{~F}_{3}$ and $\mathrm{NaV}_{2}\left(\mathrm{PO}_{4}\right)_{2} \mathrm{~F}_{3}$, and applied them to the four different ways to distribute the $\mathrm{F}^{-} / \mathrm{O}^{2-}$ ions as described in ${ }^{50}$. The input models were first relaxed until they reached their minimum energy and the electronic density on each atom was thus calculated on the optimized structures. The 3D crystal structure and the spin distribution map of the optimized structures were visualized using VESTA..$^{51}$

\section{- RESULTS AND DISCUSSION}

XAS Characterization on $\mathrm{Na}_{3} \mathrm{~V}_{2}\left(\mathrm{PO}_{4}\right)_{2} \mathrm{~F}_{3}$, $\mathrm{Na}_{3} \mathrm{~V}_{2}\left(\mathrm{PO}_{4}\right)_{2} \mathrm{~F}_{2} \mathrm{O}$, and $\mathrm{Na}_{3} \mathrm{~V}_{\mathbf{2}}\left(\mathrm{PO}_{4}\right)_{2} \mathrm{~F}_{1.5} \mathrm{O}_{1.5}$. Before investigating the vanadium redox mechanism in $\mathrm{Na}_{3} \mathrm{~V}_{2}\left(\mathrm{PO}_{4}\right)_{2} \mathrm{~F}_{3-y} \mathrm{O}_{y}$ $(0 \leq y \leq 2)$, we first compare the $\mathrm{X}$-ray absorption near edge structure (XANES) spectra recorded on the pristine materials to identify their fingerprints in the pre-edge and edge regions. The $\mathrm{V}$ K-edge XANES spectra recorded on the three pristine materials, $\quad \mathrm{Na}_{3} \mathrm{~V}_{2}\left(\mathrm{PO}_{4}\right)_{2} \mathrm{~F}_{3}, \quad \mathrm{Na}_{3} \mathrm{~V}_{2}\left(\mathrm{PO}_{4}\right)_{2} \mathrm{~F}_{2} \mathrm{O}, \quad$ and $\mathrm{Na}_{3} \mathrm{~V}_{2}\left(\mathrm{PO}_{4}\right)_{2} \mathrm{~F}_{1.5} \mathrm{O}_{1.5}$ as compared to $\mathrm{V}^{3+} \mathrm{PO}_{4}, \mathrm{LiV}^{4+} \mathrm{OPO}_{4}$, $\mathrm{Na}_{3} \mathrm{~V}^{4+}{ }_{2}\left(\mathrm{PO}_{4}\right)_{2} \mathrm{FO}_{2}$, and $\mathrm{V}^{5+} \mathrm{OPO}_{4}$ references are presented in Figure 2. The edge energy of the three aforementioned samples falls in the energy range between $\mathrm{V}^{3+} \mathrm{PO}_{4}$ and $\mathrm{LiV}^{4+} \mathrm{OPO}_{4}$, thus indicating an oxidation state between +3 and +4 . In $\mathrm{Na}_{3} \mathrm{~V}_{2}\left(\mathrm{PO}_{4}\right)_{2} \mathrm{~F}_{3}(y=0)$ the intensity of the pre-edge signal is rather weak as all the vanadium ions are trivalent and localized in the symmetric octahedral site $\mathrm{F}-\mathrm{O}_{4} \mathrm{~V}^{3+}-\mathrm{F}$, where all the surrounding bond lengths are $\sim 2.0 \AA^{19,50}$, and the $1 s \rightarrow 3 d$ transition in the pre-edge is forbidden. ${ }^{52-55}$ In the case of $\mathrm{Na}_{3} \mathrm{~V}_{2}\left(\mathrm{PO}_{4}\right)_{2} \mathrm{~F}_{2} \mathrm{O}(y=1), 50 \%$ of the $\mathrm{F}-\mathrm{O}_{4} \mathrm{~V}^{3+}-\mathrm{F}$ local environments are replaced by $\mathrm{F}-\mathrm{V}^{4+} \mathrm{O}_{4}=\mathrm{O}$ together with the formation of the highly covalent vanadyl bond $\left(d_{\mathrm{V}=\mathrm{O}}=\sim 1.62 \AA\right)$, which distorts the vanadium local environment and increases the probability for the $1 s \rightarrow 3 d$ transition to occur. Indeed, the $\mathrm{V} \mathrm{K}$-edge XANES spectrum recorded on the pristine $\mathrm{Na}_{3} \mathrm{~V}_{2}\left(\mathrm{PO}_{4}\right)_{2} \mathrm{~F}_{2} \mathrm{O}$ shows an intense pre-edge signal at $5469.5 \mathrm{eV}$ (Figure 2); the more $\mathrm{F}-\mathrm{V}^{4+} \mathrm{O}_{4}=\mathrm{O}$ present in the structure, the more intense the pre-edge signal is. As compared to $\mathrm{Na}_{3} \mathrm{~V}_{2}\left(\mathrm{PO}_{4}\right)_{2} \mathrm{~F}_{3}$, the absorption edge of $\mathrm{Na}_{3} \mathrm{~V}_{2}\left(\mathrm{PO}_{4}\right)_{2} \mathrm{~F}_{3-y} \mathrm{O}_{y}(0<y \leq 2)$ oxygenated phases shifts slightly to a higher energy due to the gradual replacement of $\mathrm{F}-\mathrm{O}_{4} \mathrm{~V}^{3+}-\mathrm{F}$ by $\mathrm{F}-\mathrm{V}^{4+} \mathrm{O}_{4}=\mathrm{O}$ and the difference in the covalency of $\mathrm{V}^{\mathrm{n}+}-\mathrm{X}$ bonds. Nonetheless, in this case, the edge position is not a reliable criterion to discriminate different members in this family of materials. The pre-edge signal is the indeed signature that is much more sensitive to changes in the vanadium oxidation state and that must be used to identify the $\mathrm{Na}_{3} \mathrm{~V}_{2}\left(\mathrm{PO}_{4}\right)_{2} \mathrm{~F}_{3-y} \mathrm{O}_{y}$ compositions.

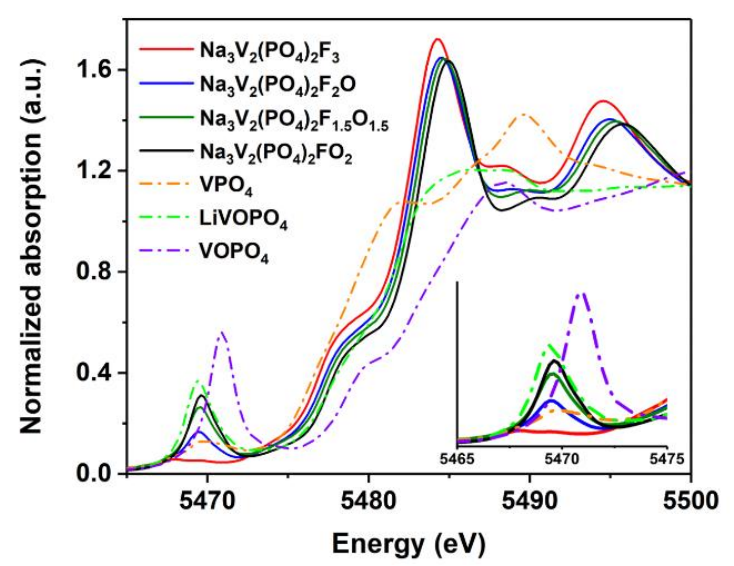

Figure 2. Vanadium K-edge XANES spectra recorded on the three pristine materials $\mathrm{Na}_{3} \mathrm{~V}_{2}\left(\mathrm{PO}_{4}\right)_{2} \mathrm{~F}_{3}, \quad \mathrm{Na}_{3} \mathrm{~V}_{2}\left(\mathrm{PO}_{4}\right)_{2} \mathrm{~F}_{2} \mathrm{O}$, and $\mathrm{Na}_{3} \mathrm{~V}_{2}\left(\mathrm{PO}_{4}\right)_{2} \mathrm{~F}_{1.5} \mathrm{O}_{1.5}$. The ex situ $\mathrm{V}^{3+} \mathrm{PO}_{4}$, $\mathrm{LiV}^{4+} \mathrm{OPO}_{4}$, $\mathrm{Na}_{3} \mathrm{~V}^{4+}{ }_{2}\left(\mathrm{PO}_{4}\right)_{2} \mathrm{FO}_{2}$, and $\mathrm{V}^{5+} \mathrm{OPO}_{4}$ samples were used as references to determine the oxidation state of vanadium species. Inset shows a zoom on the pre-edge region between 5465 and $5475 \mathrm{eV}$.

The $\mathrm{Na}_{3} \mathrm{~V}_{2}\left(\mathrm{PO}_{4}\right)_{2} \mathrm{~F}_{3}-\mathrm{NaV}_{2}\left(\mathrm{PO}_{4}\right)_{2} \mathrm{~F}_{3}$ System. As explained earlier, the $\mathrm{V}$ K-edge XANES spectrum recorded on $\mathrm{Na}_{3} \mathrm{~V}_{2}\left(\mathrm{PO}_{4}\right)_{2} \mathrm{~F}_{3}$ is characterized by a negligible pre-edge signal. 
The Fourier transformation is applied on the XAS spectrum and an EXAFS fit is performed in order to reconfirm the symmetric local environment of the vanadium absorber. In $\mathrm{Na}_{3} \mathrm{~V}_{2}\left(\mathrm{PO}_{4}\right)_{2} \mathrm{~F}_{3}$, the $\mathrm{F}-\mathrm{O}_{4} \mathrm{~V}^{3+}-\mathrm{F}-\mathrm{V}^{3+} \mathrm{O}_{4}-\mathrm{F}$ bioctahedral units generate twelve $\mathrm{V}^{3+}-\mathrm{F} / \mathrm{O}$ distances; nonetheless, the synchrotron $\mathrm{X}$-ray diffraction (SXRD) data showed that the two $\mathrm{V}^{3+}$ ions in the same bioctahedron are equivalent ${ }^{19,20}$ and thus the fitting model can be reduced to a single octahedron $\mathrm{F}-\mathrm{O}_{4} \mathrm{~V}^{3+}-\mathrm{F}$. The EXAFS model is defined by using one common parameter for all the $\mathrm{V}^{3+}-\mathrm{F} / \mathrm{O}$ distances and another parameter for the Debye-Waller factor associated to the six $\mathrm{F}^{-} / \mathrm{O}^{2-}$ ligands. The results reveal that $\mathrm{V}^{3+}$ is coordinated by six $\mathrm{F} / \mathrm{O}$ ligands at an average distance of 2.003(5) $\AA$ and $\sigma=3.3(5) \cdot 10^{-3} \AA^{2}$ (Figure 3), which is in agreement with the negligible pre-edge signal and the structural data determined by SXRD. ${ }^{19,20}$ Upon charging an $\mathrm{Na} / / \mathrm{Na}_{3} \mathrm{~V}_{2}\left(\mathrm{PO}_{4}\right)_{2} \mathrm{~F}_{3}$ half-cell, the XANES spectra evolve linearly (Figure 4a) and the edge energy (taken at normalized absorption equals to 1.0) shifts gradually from $5482.0 \mathrm{eV}$ to $5484.8 \mathrm{eV}$ (Figure S2), thus implying the oxidation of $\mathrm{V}^{3+}$ to higher oxidation states. ${ }^{18,25}$

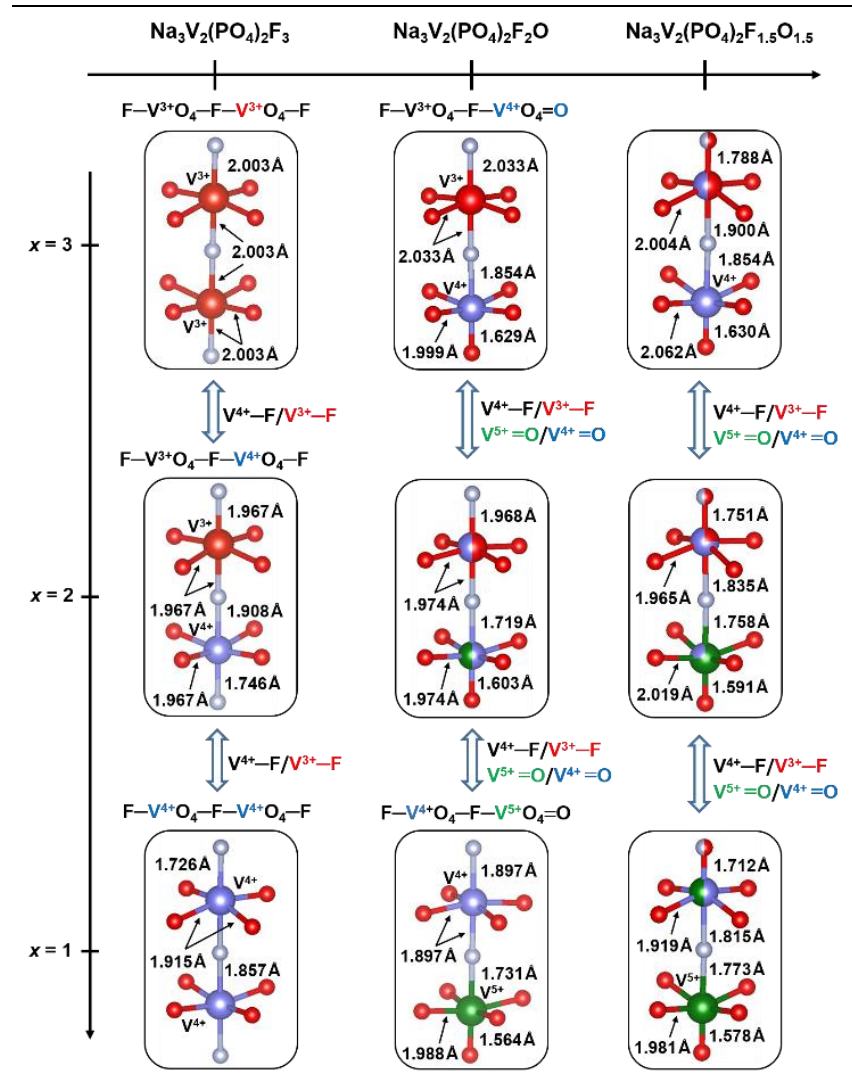

Figure 3. Average vanadium local environments determined by EXAFS analysis performed on the reconstructed EXAFS spectra of the principal components determined for the three systems $\mathrm{Na}_{3} \mathrm{~V}_{2}\left(\mathrm{PO}_{4}\right)_{2} \mathrm{~F}_{3}-\mathrm{NaV}_{2}\left(\mathrm{PO}_{4}\right)_{2} \mathrm{~F}_{3}, \mathrm{Na}_{3} \mathrm{~V}_{2}\left(\mathrm{PO}_{4}\right)_{2} \mathrm{~F}_{2} \mathrm{O}-\mathrm{NaV}_{2}\left(\mathrm{PO}_{4}\right)_{2} \mathrm{~F}_{2} \mathrm{O}$ and $\mathrm{Na}_{3} \mathrm{~V}_{2}\left(\mathrm{PO}_{4}\right)_{2} \mathrm{~F}_{1.5} \mathrm{O}_{1.5}-\mathrm{NaV}_{2}\left(\mathrm{PO}_{4}\right)_{2} \mathrm{~F}_{1.5} \mathrm{O}_{1.5}$. The vanadium redox couples involved in the desodiation process are indicated on the double-headed arrows. The $\mathrm{Na}^{+}$content ( $x$ value) for each composition is given on the left arrow. $\mathrm{V}^{3+}, \mathrm{V}^{4+}$ and $\mathrm{V}^{5+}$ ions are represented by red, light violet and dark green spheres while oxygen and fluorine are represented by red and light blue spheres, respectively. The octahedral sub-units used in EXAFS analysis are represented in form of bioctahedra in order to emphasize the existence of bioctahedral units in these structures. $\uparrow$ The distances of mixed sites in $\mathrm{Na}_{3} \mathrm{~V}_{2}\left(\mathrm{PO}_{4}\right)_{2} \mathrm{~F}_{1.5} \mathrm{O}_{1.5}-\mathrm{NaV}_{2}\left(\mathrm{PO}_{4}\right)_{2} \mathrm{~F}_{1.5} \mathrm{O}_{1.5}$ are average values of the symmetric and distorted sites reported in Table S3.
A PCA analysis performed on the whole XAS spectra shows that three independent components are required to describe the $\mathrm{Na}_{3} \mathrm{~V}_{2}\left(\mathrm{PO}_{4}\right)_{2} \mathrm{~F}_{3}-\mathrm{NaV}_{2}\left(\mathrm{PO}_{4}\right)_{2} \mathrm{~F}_{3}$ system (Figure $4 \mathrm{~b}$ ), which is in agreement with our previous results. ${ }^{25}$ We had earlier related the nature of these components to the $\mathrm{F}-\mathrm{O}_{4} \mathrm{~V}^{3+}-\mathrm{F}-\mathrm{V}^{3+} \mathrm{O}_{4}-\mathrm{F}, \quad \mathrm{F}-\mathrm{O}_{4} \mathrm{~V}^{3+}-\mathrm{F}-\mathrm{V}^{4+} \mathrm{O}_{4}-\mathrm{F} \quad$ and $\mathrm{F}-\mathrm{O}_{4} \mathrm{~V}^{3+}-\mathrm{F}-\mathrm{V}^{5+} \mathrm{O}_{4}-\mathrm{F}$ bioctahedral units, respectively. This attribution was based on the structural changes observed by $o p$ erando SXRD recorded on the $\mathrm{Na}_{3} \mathrm{~V}_{2}\left(\mathrm{PO}_{4}\right)_{2} \mathrm{~F}_{3}-\mathrm{NaV}_{2}\left(\mathrm{PO}_{4}\right)_{2} \mathrm{~F}_{3}$ system upon electrochemical operation. We also reported that the $\mathrm{NaV}_{2}\left(\mathrm{PO}_{4}\right)_{2} \mathrm{~F}_{3}$ composition is characterized by the presence of $\mathrm{F}-\mathrm{O}_{4} \mathrm{~V}^{3+}-\mathrm{F}-\mathrm{V}^{5+} \mathrm{O}_{4}-\mathrm{F}$ bioctahedral units where the $\mathrm{F}-\mathrm{O}_{4} \mathrm{~V}^{3+}-\mathrm{F}$ site presents the 'quasi'-octahedral symmetry while the $\mathrm{F}-\mathrm{V}^{5+} \mathrm{O}_{4}-\mathrm{F}$ site is highly distorted due to the formation of an abnormally short $\mathrm{V}^{5+}-\mathrm{F}$ bond $(\sim 1.67(4) \AA) .{ }^{56}$ Consequently, no XANES signature of $\mathrm{V}^{4+}$ is expected at the end of charge as $\mathrm{NaV}_{2}\left(\mathrm{PO}_{4}\right)_{2} \mathrm{~F}_{3}$ would contain only $\mathrm{F}-\mathrm{O}_{4} \mathrm{~V}^{3+}-\mathrm{F}-\mathrm{V}^{5+} \mathrm{O}_{4}-\mathrm{F}$. In practice, the $\mathrm{V}^{5+} \mathrm{XANES}$ signature is detected upon charge; however, $\mathrm{V}^{4+}$ is still the dominant vanadium species even at the end of charge (Figure 4a), which is not the expected observation.

As mentioned above, the PCA analysis performed on the $\mathrm{Na}_{3} \mathrm{~V}_{2}\left(\mathrm{PO}_{4}\right)_{2} \mathrm{~F}_{3}-\mathrm{NaV}_{2}\left(\mathrm{PO}_{4}\right)_{2} \mathrm{~F}_{3}$ system indicates the presence of three independent components. Evidently, the first principal component corresponds to $\mathrm{F}-\mathrm{O}_{4} \mathrm{~V}^{3+}-\mathrm{F}-\mathrm{V}^{3+} \mathrm{O}_{4}-\mathrm{F}$ bioctahedron, which is the only vanadium local environment that can exist in the $\mathrm{Na}_{3} \mathrm{~V}_{2}\left(\mathrm{PO}_{4}\right)_{2} \mathrm{~F}_{3}$, and the EXAFS analysis for this component was reported in Figure 3. The second component is formed upon charging and its concentration reaches the maximum value at spectrum \#20, and thus its nature should be linked to the nominal composition $\mathrm{Na}_{2} \mathrm{~V}_{2}\left(\mathrm{PO}_{4}\right)_{2} \mathrm{~F}_{3}$ (Figure $4 \mathrm{c}$ ). Firstprinciples DFT calculations were performed on the $\mathrm{Na}_{2} \mathrm{~V}_{2}\left(\mathrm{PO}_{4}\right)_{2} \mathrm{~F}_{3}$ composition to gain an insightful understanding on the nature of this principal component. The spin distribution map calculated on $\mathrm{Na}_{2} \mathrm{~V}_{2}\left(\mathrm{PO}_{4}\right)_{2} \mathrm{~F}_{3}$ structure shows the presence of a charge ordering on vanadium sites, where the vanadium oxidation tends to occur on two vanadium ions of the same bioctahedral unit rather than occurring randomly on different bioctahedra (Figure S3 and Figure S4a). Consequently, the electronic structure of $\mathrm{Na}_{2} \mathrm{~V}_{2}\left(\mathrm{PO}_{4}\right)_{2} \mathrm{~F}_{3}$ is characterized by the presence of an equal amount of $\mathrm{F}-\mathrm{O}_{4} \mathrm{~V}^{3+}-\mathrm{F}-\mathrm{V}^{3+} \mathrm{O}_{4}-\mathrm{F}$ and $\mathrm{F}-\mathrm{O}_{4} \mathrm{~V}^{4+}-\mathrm{F}-\mathrm{V}^{4+} \mathrm{O}_{4}-\mathrm{F}$. The co-existence of two different types of bioctahedral unit increases significantly the number of distances that needs to be included in an EXAFS fit. In our experimental conditions, however, the maximum parameter that can be included in an EXAFS fit is limited to 6, hence an average model had to be used: The $\mathrm{F}-\mathrm{O}_{4} \mathrm{~V}^{3+}-\mathrm{F}-\mathrm{V}^{3+} \mathrm{O}_{4}-\mathrm{F}$ and $\mathrm{F}-\mathrm{O}_{4} \mathrm{~V}^{4+}-\mathrm{F}-\mathrm{V}^{4+} \mathrm{O}_{4}-\mathrm{F}$ bioctahedra were thus broken down into the $\mathrm{F}-\mathrm{O}_{4} \mathrm{~V}^{3+}-\mathrm{F}$ and $\mathrm{F}-\mathrm{O}_{4} \mathrm{~V}^{4+}-\mathrm{F}$ sub-units, respectively, which are equally present in the $\mathrm{Na}_{2} \mathrm{~V}_{2}\left(\mathrm{PO}_{4}\right)_{2} \mathrm{~F}_{3}$ composition. We assumed that the $\mathrm{V}^{3+}$ site can retain its symmetric octahedral geometry during the whole charge/discharge and thus a single parameter was used to describe the six $\mathrm{V}^{3+}-\mathrm{F} / \mathrm{O}$ bond lengths. On the other hand, as a slight local distortion could occur on the $\mathrm{V}^{4+}$ site, three different distance parameters were used to describe that environment: one for the terminal $\mathrm{V}^{4+}-\mathrm{F}$ bond, a common parameter for the four equatorial $\mathrm{V}^{4+}-\mathrm{O}$ bonds and the third for the bridging $\mathrm{V}^{4+}-\mathrm{F}$ bond. This can be depicted as a [6] $+[4+1+1]$ fitting model with one common Debye-Waller factor applied for all $\mathrm{F}^{-} / \mathrm{O}^{2-}$ scatterers (corresponding thus to 5 independent parameters). The quality of the EXAFS fit in the $\mathrm{R}$-space and in the $k$-space is given in Figure $4 \mathrm{~d}$ and Figure S5. 

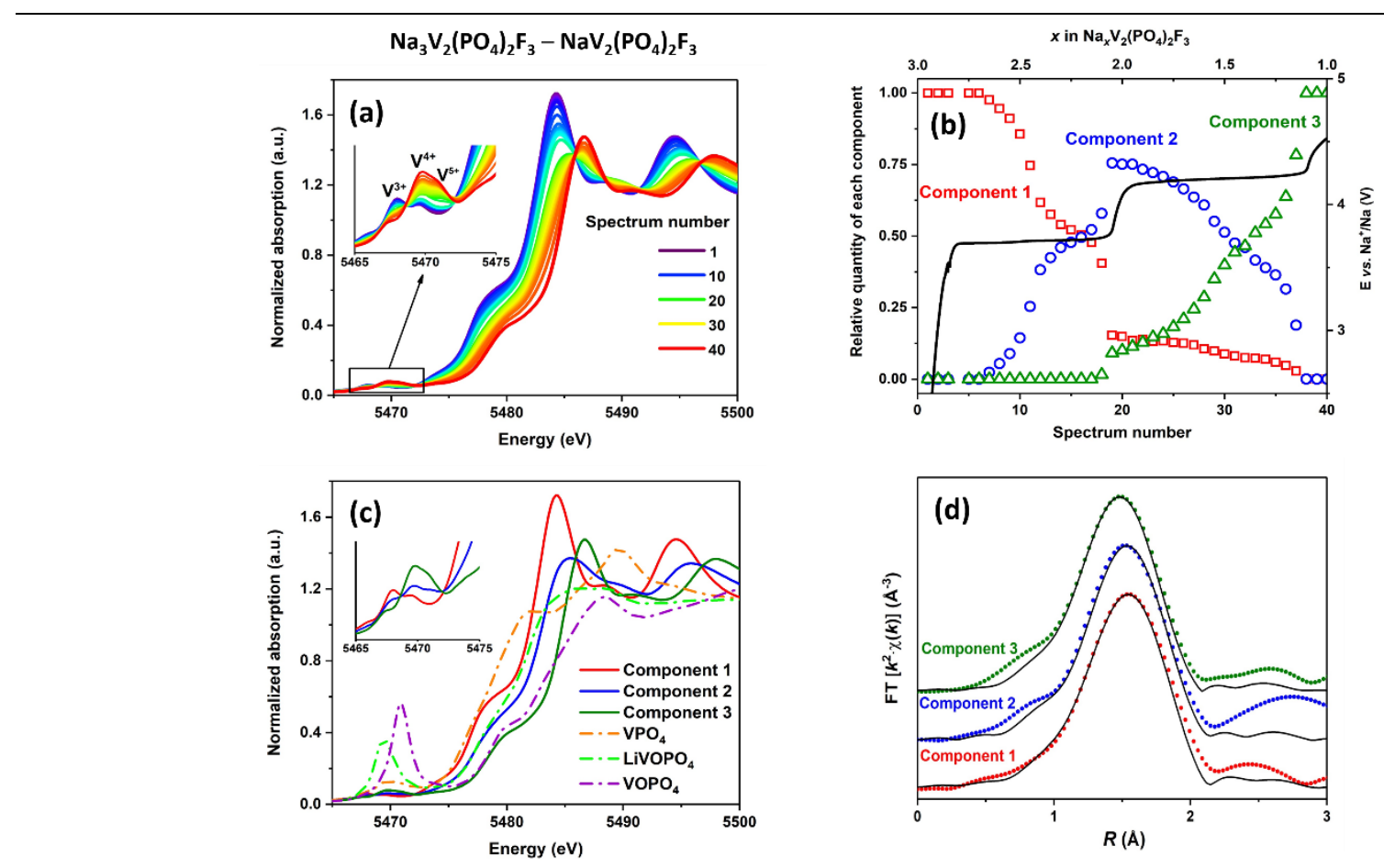

Figure 4. (a) Operando Vanadium K-edge XANES spectra recorded on an $\mathrm{Na} / / \mathrm{Na}_{3} \mathrm{~V}_{2}\left(\mathrm{PO}_{4}\right)_{2} \mathrm{~F}_{3}$ half-cell from 2.5 to $4.5 \mathrm{~V}$ vs $\mathrm{Na}+\mathrm{Na}^{+}$Inset focuses on the pre-edge area. (b) Concentration profile of the three principal components required to describe the XAS spectra recorded operando on an $\mathrm{Na} / / \mathrm{Na}_{3} \mathrm{~V}_{2}\left(\mathrm{PO}_{4}\right)_{2} \mathrm{~F}_{3}$ half-cell upon charging from 2.5 to $4.5 \mathrm{~V} \mathrm{vs} \mathrm{Na}^{+} / \mathrm{Na}$. The corresponding electrochemical profile is shown as black solid curve. (c) Reconstructed XANES spectra of the three independent components required to describe the $\mathrm{Na}_{3} \mathrm{~V}_{2}\left(\mathrm{PO}_{4}\right)_{2} \mathrm{~F}_{3}-\mathrm{NaV}_{2}\left(\mathrm{PO}_{4}\right)_{2} \mathrm{~F}_{3}$ system as compared to the $\mathrm{VPO}_{4}, \mathrm{LiVOPO}_{4}$ and $\mathrm{VOPO}_{4}$ references. Inset focuses on the pre-edge area of the reconstructed spectra. (d) Fit of the $k^{2}$-weighted Fourier transformed Vanadium K-edge EXAFS spectra $\left(k\right.$-range: $2.7-11.6 \AA^{-1}$, sine window) in the R space (R-range: 1.0-2.1 $\AA, d \mathrm{R}=0$, sine window) for the three components determined for the $\mathrm{Na}_{3} \mathrm{~V}_{2}\left(\mathrm{PO}_{4}\right)_{2} \mathrm{~F}_{3}-\mathrm{NaV}_{2}\left(\mathrm{PO}_{4}\right)_{2} \mathrm{~F}_{3}$ system

The refined bond length values and Debye-Waller factors are given in Figure 3 and Table S1. The EXAFS analysis shows a slight contraction in $\mathrm{V}-\mathrm{F} / \mathrm{O}$ distances of the $\mathrm{F}-\mathrm{V}^{4+} \mathrm{O}_{4}-\mathrm{F}$ unit while those of $\mathrm{F}-\mathrm{O}_{4} \mathrm{~V}^{3+}-\mathrm{F}$ are unlikely to be affected. Furthermore, the bond shortening in $\mathrm{F}-\mathrm{V}^{4+} \mathrm{O}_{4}-\mathrm{F}$ seems to be anisotropic and to occur preferentially along the axial direction of the bioctahedron (Figure 3). The charge ordering on vanadium bioctahedra in $\mathrm{Na}_{2} \mathrm{~V}_{2}\left(\mathrm{PO}_{4}\right)_{2} \mathrm{~F}_{3}$ seems to be the reason for the formation of a superstructure, which was earlier detected by operando synchrotron XRD, but its actual structure has not been fully resolved. ${ }^{56}$

The third principal component appears in the middle of charge and reached its maximum concentration at the end of charge; hence, this component is related to the charge ordering on vanadium ions in the $\mathrm{NaV}_{2}\left(\mathrm{PO}_{4}\right)_{2} \mathrm{~F}_{3}$ composition. The charge and spin distribution maps of $\mathrm{NaV}_{2}\left(\mathrm{PO}_{4}\right)_{2} \mathrm{~F}_{3}$, calculated in GGA and $\mathrm{GGA}+U$ methods, show the presence of only $\mathrm{F}-\mathrm{O}_{4} \mathrm{~V}^{4+}-\mathrm{F}-\mathrm{V}^{4+} \mathrm{O}_{4}-\mathrm{F}$ bioctahedra (Figure $\mathrm{S} 4 \mathrm{~b}$ ). This observation is in agreement with the earlier work of Dacek et al. ${ }^{49}$ Theoretically, there are several ways to distribute $\mathrm{Na}^{+}$ions in $\mathrm{NaV}_{2}\left(\mathrm{PO}_{4}\right)_{2} \mathrm{~F}_{3}$, and their distribution may have an influence on the oxidation state of the vanadium ions. In order to examine whether the $\mathrm{Na}^{+}$distribution in $\mathrm{NaV}_{2}\left(\mathrm{PO}_{4}\right)_{2} \mathrm{~F}_{3}$ would have an influence on the formation of $\mathrm{V}^{5+}$ or not, a supercell was created by doubling the size of the unit cell along the $c$ direction: all the $\mathrm{Na}^{+}$ions were segregated in half of the cell, while all the $\mathrm{Na}^{+}$ sites on the other half were completely empty (Figure S6). This supercell could possibly depict the actual structure in non-equilibrium conditions, such as during the charge of the battery at high rates. The spin distribution map calculated for this optimized supercell structure shows the co-existence of $\mathrm{V}^{3+} \mathrm{O}_{4} \mathrm{~F}_{2}$,
$\mathrm{V}^{4+} \mathrm{O}_{4} \mathrm{~F}_{2}$ and $\mathrm{V}^{5+} \mathrm{O}_{4} \mathrm{~F}_{2}$ sub-octahedra (Figure 5). $\mathrm{V}^{3+} \mathrm{O}_{4} \mathrm{~F}_{2}$ units are found in the area where the $\mathrm{Na}^{+}$segregation occurs while the $\mathrm{V}^{5+} \mathrm{O}_{4} \mathrm{~F}_{2}$ sub-octahedra are encountered in the area where there is no $\mathrm{Na}^{+}$ion. Therefore, the formation of $\mathrm{V}^{3+} \mathrm{O}_{4} \mathrm{~F}_{2}$, $\mathrm{V}^{4+} \mathrm{O}_{4} \mathrm{~F}_{2}$ and $\mathrm{V}^{5+} \mathrm{O}_{4} \mathrm{~F}_{2}$ in the $\mathrm{NaV}_{2}\left(\mathrm{PO}_{4}\right)_{2} \mathrm{~F}_{3}$ composition also depends on the $\mathrm{Na}^{+}$distribution in the diffusion channels. The normalized total energy per formula unit of the $\mathrm{NaV}_{2}\left(\mathrm{PO}_{4}\right)_{2} \mathrm{~F}_{3}$ supercell (Figure 5) is $-431.78 \mathrm{eV}$ as compared to $-433.16 \mathrm{eV}$ for the structure where $\mathrm{Na}^{+}$ions are homogeneously distributed (Figure $\mathrm{S} 4 \mathrm{~b}$ ), and thus the $\mathrm{Na}^{+}$segregation and the formation of $\mathrm{V}^{5+} \mathrm{O}_{4} \mathrm{~F}_{2}$ are unlikely to happen in $\mathrm{NaV}_{2}\left(\mathrm{PO}_{4}\right)_{2} \mathrm{~F}_{3}$ in thermodynamic conditions. However, this $\mathrm{Na}^{+}$segregation can certainly occur during electrochemical operation and thus contribute to the formation of $\mathrm{V}^{5+}$ in $\mathrm{NaV}_{2}\left(\mathrm{PO}_{4}\right)_{2} \mathrm{~F}_{3}$ as evidenced by operando SXRD combined with Rietveld refinement and bond valence sum analysis ${ }^{56},{ }^{51} \mathrm{~V}$ ss-NMR ${ }^{25}$ and by the present operando XAS study. Based on our DFT calculation results, it seems that the $\mathrm{Na}^{+}$segregation occurs on a very local scale to favor the partial formation of $\mathrm{V}^{5+}$, which has been observed experimentally.

The third principal component observed by PCA is possibly linked to the charge ordering on vanadium ions in $\mathrm{NaV}_{2}\left(\mathrm{PO}_{4}\right)_{2} \mathrm{~F}_{3}$; nonetheless, the nature of this charge ordering is difficult to identify due to the complexity of the electrochemical reaction at high-voltage. The presence of $\mathrm{V}^{5+}$ at the end of charge is undeniable, but a quantification analysis is not feasible because of the weak intensity in the pre-edge region (Figure 4a). When performing the EXAFS analysis, we assumed that all bioctahedra in $\mathrm{NaV}_{2}\left(\mathrm{PO}_{4}\right)_{2} \mathrm{~F}_{3}$ can be 'averagely' described as $\mathrm{F}-\mathrm{O}_{4} \mathrm{~V}^{4+}-\mathrm{F}-\mathrm{V}^{4+} \mathrm{O}_{4}-\mathrm{F}$. Due to the limited number of parameters that can be refined, the two vanadium sites in $\mathrm{F}-\mathrm{O}_{4} \mathrm{~V}^{4+}-\mathrm{F}-\mathrm{V}^{4+} \mathrm{O}_{4}-\mathrm{F}$ were assumed to be equivalent and the 
EXAFS spectrum was fit using the $[4+1+1]$ model, which allows the possible local distortion to occur on the apical positions. In this model, a common parameter was used to describe the four $\mathrm{V}-\mathrm{O}$ bond lengths in the equatorial plane, one for the sharing $\mathrm{V}-\mathrm{F}$ bond and one other for the apical $\mathrm{V}-\mathrm{F}$ bond. The refined bond length values and Debye-Waller factor of this component are given in Figure 3 and Table S1. The vanadium sites in $\mathrm{NaV}_{2}\left(\mathrm{PO}_{4}\right)_{2} \mathrm{~F}_{3}$ are greatly distorted as compared to its initial state in $\mathrm{Na}_{3} \mathrm{~V}_{2}\left(\mathrm{PO}_{4}\right)_{2} \mathrm{~F}_{3}$. Nonetheless, it has to be pointed out that it remains an average information due to the complexity and diversity of vanadium local environments in this composition.

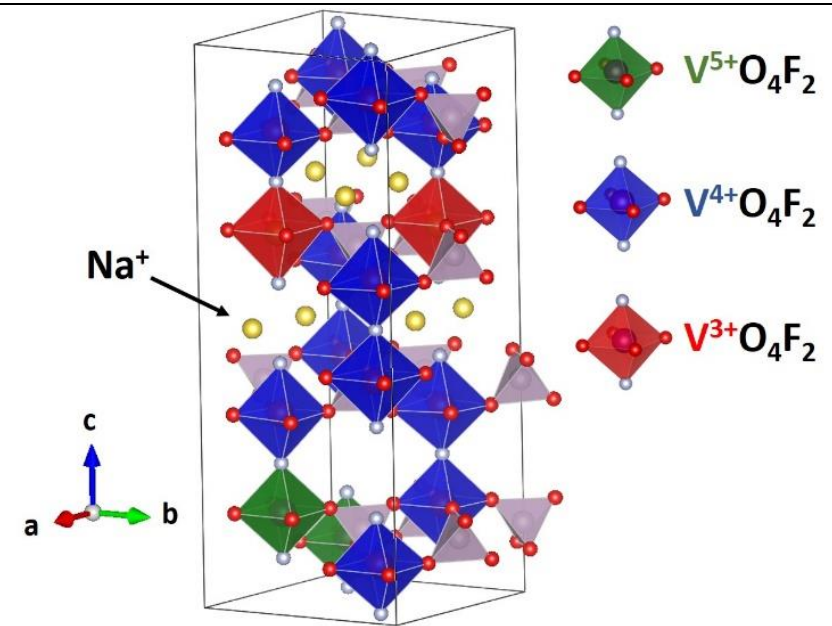

Figure 5. Optimized structure of $\mathrm{NaV}_{2}\left(\mathrm{PO}_{4}\right)_{2} \mathrm{~F}_{3}$ supercell. The location of $\mathrm{V}^{3+} \mathrm{O}_{4} \mathrm{~F}_{2}, \mathrm{~V}^{4+} \mathrm{O}_{4} \mathrm{~F}_{2}$ and $\mathrm{V}^{5+} \mathrm{O}_{4} \mathrm{~F}_{2}$ sub-units is indicated by red, blue and green octahedra, respectively.

The $\mathrm{Na}_{3} \mathrm{~V}_{2}\left(\mathrm{PO}_{4}\right)_{2} \mathrm{~F}_{2} \mathrm{O}-\mathrm{NaV}_{2}\left(\mathrm{PO}_{4}\right)_{2} \mathrm{~F}_{2} \mathrm{O}$ System. In $\mathrm{Na}_{3} \mathrm{~V}_{2}\left(\mathrm{PO}_{4}\right)_{2} \mathrm{~F}_{2} \mathrm{O}$, there exist the same quantity of $\mathrm{F}-\mathrm{O}_{4} \mathrm{~V}^{3+}-\mathrm{F}$ and $\mathrm{F}-\mathrm{V}^{4+} \mathrm{O}_{4}=\mathrm{O}$ sub-units. By the use of ss-NMR spectroscopy and first-principles DFT calculations, we have recently illustrated that these sub-units are randomly distributed in the lattices to generate $\quad \mathrm{F}-\mathrm{O}_{4} \mathrm{~V}^{3+}-\mathrm{F}-\mathrm{V}^{3+} \mathrm{O}_{4}-\mathrm{F}$, $\mathrm{F}-\mathrm{O}_{4} \mathrm{~V}^{3+}-\mathrm{F}-\mathrm{V}^{4+} \mathrm{O}_{4}=\mathrm{O}$ and $\mathrm{O}=\mathrm{O}_{4} \mathrm{~V}^{4+}-\mathrm{F}-\mathrm{V}^{4+} \mathrm{O}_{4}=\mathrm{O}$ bioctahedra. ${ }^{50}$ As explained earlier, the limited number of independent parameters that can be included in the EXAFS fit (i.e. 6 in our case) implies us to consider an average model by breaking all the aforementioned bioctahedra into $\mathrm{F}-\mathrm{O}_{4} \mathrm{~V}^{3+}-\mathrm{F}$ and $\mathrm{F}-\mathrm{V}^{4+} \mathrm{O}_{4}=\mathrm{O}$ sub-units in the $1 / 1$ ratio. First-principles DFT calculations have shown that the $\mathrm{F}-\mathrm{O}_{4} \mathrm{~V}^{3+}-\mathrm{F}$ environment is completely symmetric whereas the $\mathrm{F}-\mathrm{V}^{4+} \mathrm{O}_{4}=\mathrm{O}$ one is greatly distorted due to the short vanadyl bond. ${ }^{50}$ Hence, a [6] $+[4+1+$ 1] fitting model was used where one common parameter represented the six equivalent bond lengths in the symmetric $\mathrm{F}-\mathrm{O}_{4} \mathrm{~V}^{3+}-\mathrm{F}$ environment and three parameters were required to describe the four equatorial $\mathrm{V}^{4+}-\mathrm{O}$ bonds, the bridging $\mathrm{V}^{4+}-\mathrm{F}$ bond, and the short apical $\mathrm{V}^{4+}=\mathrm{O}$ bond of the $\mathrm{F}-\mathrm{V}^{4+} \mathrm{O}_{4}=\mathrm{O}$ environment. The fitting results are gathered in Figure 6 and Table $\mathrm{S} 2$. In practice, $\mathrm{F}-\mathrm{O}_{4} \mathrm{~V}^{3+}-\mathrm{F}$ and $\mathrm{F}-\mathrm{V}^{4+} \mathrm{O}_{4}=\mathrm{O}$ sub-units are randomly distributed in $\mathrm{Na}_{3} \mathrm{~V}_{2}\left(\mathrm{PO}_{4}\right)_{2} \mathrm{~F}_{2} \mathrm{O}$, and only one average environment can be observed by SXRD with an average terminal $\mathrm{V}-\mathrm{F} / \mathrm{O}$ bond length value of $1.816(2) \AA .{ }^{16} \mathrm{By}$ EXAFS, it is pos- sible to separate this average local environment into a symmetric $\mathrm{F}-\mathrm{O}_{4} \mathrm{~V}^{3+}-\mathrm{F}$ unit with six equivalent $d_{\mathrm{V}-\mathrm{F} / \mathrm{O}}=2.033(5) \AA$, and a distorted $\mathrm{F}-\mathrm{V}^{4+} \mathrm{O}_{4}=\mathrm{O}$ unit with four equatorial $d_{\mathrm{V}-\mathrm{O}}=$ $1.999(5) \AA$, the terminal $d_{\mathrm{V}=\mathrm{O}}=1.629(5) \AA$ and the sharing fluorine with $d_{\mathrm{V}-\mathrm{F}}=1.854(5) \AA$.

The same quantity of $\mathrm{V}^{3+}-\mathrm{F}$ and $\mathrm{V}^{4+}=\mathrm{O}$ redox centers in $\mathrm{Na}_{3} \mathrm{~V}_{2}\left(\mathrm{PO}_{4}\right)_{2} \mathrm{~F}_{2} \mathrm{O}$ represents an ideal case that can be used to investigate the reaction mechanism of vanadium redox centers in the $\mathrm{Na}_{3} \mathrm{~V}_{2}\left(\mathrm{PO}_{4}\right)_{2} \mathrm{~F}_{3-y} \mathrm{O}_{y}(0<y<2)$ compositions. There exist three possible redox mechanisms that can occur in these compositions:

(i) All $\mathrm{V}^{4+}=\mathrm{O}$ redox centers would be oxidized before $\mathrm{V}^{3+}-\mathrm{F}$. In this scenario, one could expect that after the electrochemical extraction of the first $\mathrm{Na}^{+}$ion, the pre-edge signature of the highly distorted $\mathrm{V}^{4+}=\mathrm{O}$ sites positioning at $5469.5 \mathrm{eV}$ would be shifted completely to a characteristic value of $\mathrm{V}^{5+}=\mathrm{O}$ $(5471.0 \mathrm{eV})$.

(ii) All $\mathrm{V}^{3+}-\mathrm{F}$ sites would be oxidized before $\mathrm{V}^{4+}=\mathrm{O}$. In this case, one should expect a linear evolution in the edge energy, but the position of the pre-edge signal at $5469.5 \mathrm{eV}$ would not change at all during the removal of the first $\mathrm{Na}^{+}$.

(iii) $\mathrm{V}^{4+}=\mathrm{O}$ and $\mathrm{V}^{3+}-\mathrm{F}$ redox centers would be oxidized simultaneously. In this last scenario, two intense pre-edge signals would be detected after the extraction of the first $\mathrm{Na}^{+}$ion: one would correspond to $\mathrm{V}^{4+}=\mathrm{O}($ at $\sim 5469.5 \mathrm{eV}$ ) and the other to $\mathrm{V}^{5+}=\mathrm{O}$ (at $\left.\sim 5471.0 \mathrm{eV}\right)$.

Upon charging the $\mathrm{Na} / / \mathrm{Na}_{3} \mathrm{~V}_{2}\left(\mathrm{PO}_{4}\right)_{2} \mathrm{~F}_{2} \mathrm{O}$ half-cell, the edge energy (taken at normalized absorption equals to 1.0) of the $\mathrm{V}$ K-edge XANES spectra shifts gradually from $5482.24 \mathrm{eV}$ to $5484.84 \mathrm{eV}$ indicating a progressive oxidation on vanadium sites (Figure S7). A new signal at $5471.0 \mathrm{eV}$ is observed in the pre-edge region right after the desodiation process occurs (Figure 6a) and the relative intensity of this signal increases continuously during the whole charge (Figure S8 and Figure S9). Furthermore, two intense pre-edge signals at $5469.5 \mathrm{eV}$ and $5471.0 \mathrm{eV}$ are detected in the nominal composition $\mathrm{Na}_{2} \mathrm{~V}_{2}\left(\mathrm{PO}_{4}\right)_{2} \mathrm{~F}_{2} \mathrm{O}$ (Spectrum \#40 Figure 6a) and the relative area between these two signals is 60/40 (Figure S9). The intense signal at $5471.0 \mathrm{eV}$ corresponds solely to $\mathrm{F}^{-} \mathrm{V}^{5+} \mathrm{O}_{4}=\mathrm{O}$ while the signal at $5469.5 \mathrm{eV}$ corresponds to $\mathrm{V}^{4+}$ states, including $\mathrm{F}-\mathrm{V}^{4+} \mathrm{O}_{4}-\mathrm{F}$ and $\mathrm{F}-\mathrm{V}^{4+} \mathrm{O}_{4}=\mathrm{O}$, in which $\mathrm{F}-\mathrm{V}^{4+} \mathrm{O}_{4}-\mathrm{F}$ is generated from the oxidation of $\mathrm{F}-\mathrm{V}^{3+} \mathrm{O}_{4}-\mathrm{F}$ in the initial phase. The energy difference between $\mathrm{F}-\mathrm{V}^{4+} \mathrm{O}_{4}-\mathrm{F}$ and $\mathrm{F}-\mathrm{V}^{4+} \mathrm{O}_{4}=\mathrm{O}$ is so subtle that they cannot be separated from each other. The $\mathrm{F}-\mathrm{V}^{4+} \mathrm{O}_{4}-\mathrm{F}$ sub-unit is quite symmetric (Figure 3 ) and its preedge signal is expected to be weak, but observable. This is the reason why the pre-edge signal at $5469.5 \mathrm{eV}$ does not diminish completely even at the end of charge. These observations show that the $\mathrm{V}^{4+}-\mathrm{F} / \mathrm{V}^{3+}-\mathrm{F}$ and $\left\{\mathrm{V}^{5+}=\mathrm{O}\right\}^{3+} /\left\{\mathrm{V}^{4+}=\mathrm{O}\right\}^{2+}$ redox couples are activated simultaneously in $\mathrm{Na}_{3} \mathrm{~V}_{2}\left(\mathrm{PO}_{4}\right)_{2} \mathrm{~F}_{2} \mathrm{O}$, and the same conclusion can be extended to the whole $\mathrm{Na}_{3} \mathrm{~V}_{2}\left(\mathrm{PO}_{4}\right)_{2} \mathrm{~F}_{3-y} \mathrm{O}_{y}$ $(0<y<2)$ solid solution. By calculating the Bader charge, $\mathrm{Xu}$ and co-workers suggested that the oxidation of the $\mathrm{F}-\mathrm{V}^{4+} \mathrm{O}_{4}=\mathrm{O}$ group would occur on the oxygen atom of the vanadyl bond rather than on the vanadium site, ${ }^{57}$ but these recorded XAS data indeed prove that the oxidation of $\mathrm{F}-\mathrm{V}^{4+} \mathrm{O}_{4}=\mathrm{O}$ will lead to the formation of $\mathrm{F}-\mathrm{V}^{5+} \mathrm{O}_{4}=\mathrm{O}$. 

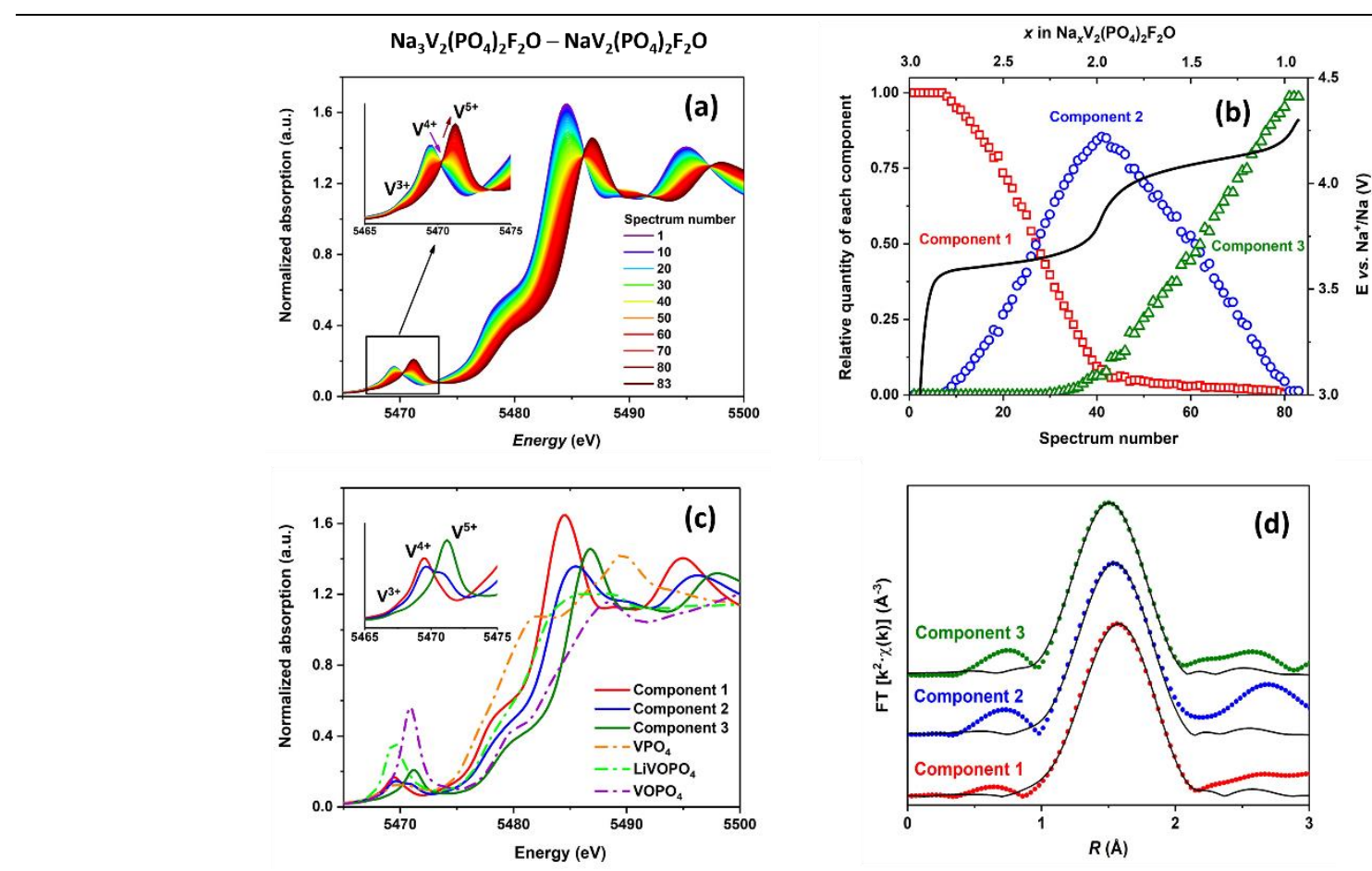

Figure 6. (a) Operando Vanadium K edge XANES spectra recorded on a Na// $\mathrm{Na}_{3} \mathrm{~V}_{2}\left(\mathrm{PO}_{4}\right)_{2} \mathrm{~F}_{2} \mathrm{O}$ half-cell from 2.5 to $4.3 \mathrm{~V}$ vs $\mathrm{Na}+\mathrm{Na}^{+}$The inset focuses on the pre-edge region. (b) Concentration profile of the three principal components required to describe the operando XAS spectra recorded on a Na//Na3 $\mathrm{V}_{2}\left(\mathrm{PO}_{4}\right)_{2} \mathrm{~F}_{2} \mathrm{O}$ half-cell upon charging from 2.5 to $4.3 \mathrm{~V} \mathrm{vs} \mathrm{Na} / \mathrm{Na}$. The corresponding electrochemical profile is shown as black solid curve. (c) Reconstructed XANES spectra of the three independent components required to describe the $\mathrm{Na}_{3} \mathrm{~V}_{2}\left(\mathrm{PO}_{4}\right)_{2} \mathrm{~F}_{2} \mathrm{O}-\mathrm{NaV}_{2}\left(\mathrm{PO}_{4}\right)_{2} \mathrm{~F}_{2} \mathrm{O}$ system as compared to the references $\mathrm{VPO}_{4}$, $\mathrm{LiVOPO}_{4}$ and $\mathrm{VOPO}_{4}$. Inset focuses on the pre-edge area of the reconstructed spectra. (d) Fit of the $k^{2}$-weighted Fourier transformed Vanadium K-edge EXAFS spectrum $\left(k\right.$-range: $2.7-11.6 \AA^{-1}$, sine window) in the $\mathrm{R}$ space (R-range: 1.0-2.1 $\AA, d \mathrm{R}=0$, sine window) for the three components determined for the $\mathrm{Na}_{3} \mathrm{~V}_{2}\left(\mathrm{PO}_{4}\right)_{2} \mathrm{~F}_{2} \mathrm{O}-\mathrm{NaV}_{2}\left(\mathrm{PO}_{4}\right)_{2} \mathrm{~F}_{2} \mathrm{O}$ system.

The PCA result shows that three independent components are required to describe the whole data set (Figure S10). The concentration profile of all the principal components is quite similar to that observed for the $\mathrm{Na}_{3} \mathrm{~V}_{2}\left(\mathrm{PO}_{4}\right)_{2} \mathrm{~F}_{3}-\mathrm{NaV}_{2}\left(\mathrm{PO}_{4}\right)_{2} \mathrm{~F}_{3}$ system (Figure 6b), and the concentration of the second component reaches its maximum value after the extraction of the first $\mathrm{Na}^{+}$. This observation implies a possible charge ordering on vanadium sites in the $\mathrm{Na}_{2} \mathrm{~V}_{2}\left(\mathrm{PO}_{4}\right)_{2} \mathrm{~F}_{2} \mathrm{O}$ composition. DFT calculations were thus employed in order to confirm this charge ordering. We have recently examined the stability of four different ways to distribute the terminal $\mathrm{F}^{-} / \mathrm{O}^{2-}$ ions in the $\mathrm{Na}_{3} \mathrm{~V}_{2}\left(\mathrm{PO}_{4}\right)_{2} \mathrm{~F}_{2} \mathrm{O}$ composition by GGA method, ${ }^{50}$ and these four input models are now reused as the starting point for the structural optimization in the GGA $+U$ approach. Concerning the input models for $\mathrm{Na}_{2} \mathrm{~V}_{2}\left(\mathrm{PO}_{4}\right)_{2} \mathrm{~F}_{2} \mathrm{O}$ and $\mathrm{NaV}_{2}\left(\mathrm{PO}_{4}\right)_{2} \mathrm{~F}_{2} \mathrm{O}$, we assumed that the $\mathrm{Na}^{+}$orderings in these phases would be similar to those observed for their counterparts, $\mathrm{Na}_{2} \mathrm{~V}_{2}\left(\mathrm{PO}_{4}\right)_{2} \mathrm{~F}_{3}$ and $\mathrm{NaV}_{2}\left(\mathrm{PO}_{4}\right)_{2} \mathrm{~F}_{3}$, and applied them to the four different ways to distribute the terminal $\mathrm{F}^{-} / \mathrm{O}^{2-}$ ions as described in ${ }^{50}$. The total energy and the charge distribution on vanadium sites obtained after the structural optimization step within the GGA+ $U$ method for each input model at the $\mathrm{Na}_{3} \mathrm{~V}_{2}\left(\mathrm{PO}_{4}\right)_{2} \mathrm{~F}_{2} \mathrm{O}, \mathrm{Na}_{2} \mathrm{~V}_{2}\left(\mathrm{PO}_{4}\right)_{2} \mathrm{~F}_{2} \mathrm{O}$ and $\mathrm{NaV}_{2}\left(\mathrm{PO}_{4}\right)_{2} \mathrm{~F}_{2} \mathrm{O}$ compositions are summarized in Figure 7. In the case of $\mathrm{Na}_{3} \mathrm{~V}_{2}\left(\mathrm{PO}_{4}\right)_{2} \mathrm{~F}_{2} \mathrm{O}, \mathrm{F}-\mathrm{V}^{3+} \mathrm{O}_{4}-\mathrm{F}$ or $\mathrm{F}-\mathrm{V}^{4+} \mathrm{O}_{4}=\mathrm{O}$ sub-octahedra are formed depending on whether its terminal ion is $\mathrm{F}^{-}$or $\mathrm{O}^{2-}$, respectively. Four different ways to distribute the terminal $\mathrm{F}^{-} / \mathrm{O}^{2-}$ ions result in four structures differed in the $\mathrm{F}-\mathrm{V}^{3+} \mathrm{O}_{4}-\mathrm{F} / \mathrm{F}-\mathrm{V}^{4+} \mathrm{O}_{4}=\mathrm{O}$ distribution (Figure 7); nonetheless, these structures possess similar stability as discussed in details in $\operatorname{Ref}^{50}$. When moving to the $\mathrm{Na}_{2} \mathrm{~V}_{2}\left(\mathrm{PO}_{4}\right)_{2} \mathrm{~F}_{2} \mathrm{O}$ composition, all the optimized structures show the co-existence of $\mathrm{F}-\mathrm{V}^{3+} \mathrm{O}_{4}-\mathrm{F}$, $\mathrm{F}-\mathrm{V}^{4+} \mathrm{O}_{4}-\mathrm{F}, \mathrm{F}-\mathrm{V}^{4+} \mathrm{O}_{4}=\mathrm{O}$ and $\mathrm{F}-\mathrm{V}^{5+} \mathrm{O}_{4}=\mathrm{O}$ octahedra, and the distribution of these sub-units depends on the position of the terminal $\mathrm{F}^{-} / \mathrm{O}^{2-}$ ions in the input model (Figure 7). These results support the simultaneous activation of the $\mathrm{V}^{4+}-\mathrm{F} / \mathrm{V}^{3+} \mathrm{O}_{4}-\mathrm{F}$ and $\left\{\mathrm{V}^{5+}=\mathrm{O}\right\}^{3+} /\left\{\mathrm{V}^{4+}=\mathrm{O}\right\}^{2+}$ redox couples as it has been observed by operando XAS at V K-edge. As it is obvious from a close observation of Figure 7, the oxidation of vanadium redox centers does not occur randomly but through a charge ordering where half of the bioctahedral units in $\mathrm{Na}_{2} \mathrm{~V}_{2}\left(\mathrm{PO}_{4}\right)_{2} \mathrm{~F}_{2} \mathrm{O}$ are oxidized and the oxidation occurs only on vanadium sites in the same bioctahedra. The nature of the two sub-units in a bioctahedron is not important, they can be identical or different, and a parallel oxidation on these two sites can always take place. In the $\mathrm{NaV}_{2}\left(\mathrm{PO}_{4}\right)_{2} \mathrm{~F}_{2} \mathrm{O}$ composition, all the calculated structures show the coexistence of $\mathrm{F}-\mathrm{V}^{4+} \mathrm{O}_{4}-\mathrm{F}$ and $\mathrm{F}-\mathrm{V}^{5+} \mathrm{O}_{4}=\mathrm{O}$ depending on whether its terminal ion is $\mathrm{F}^{-}$or $\mathrm{O}^{2-}$ (Figure 7). The nature of the terminal ion thus determines the oxidation state, the electronic structure, and the local symmetry of the vanadium ion in its initial and final states. If the terminal ion is $\mathrm{F}^{-}$, the initial state of the vanadium site will be $\mathrm{F}-\mathrm{V}^{3+} \mathrm{O}_{4}-\mathrm{F}$ and at the end of charge its final state will be $\mathrm{F}-\mathrm{V}^{4+} \mathrm{O}_{4}-\mathrm{F}$. If $\mathrm{O}^{2-}$ is the terminal ion, the corresponding initial and final states will be $\mathrm{F}-\mathrm{V}^{4+} \mathrm{O}_{4}=\mathrm{O}$ and $\mathrm{F}-\mathrm{V}^{5+} \mathrm{O}_{4}=\mathrm{O}$, respectively. 


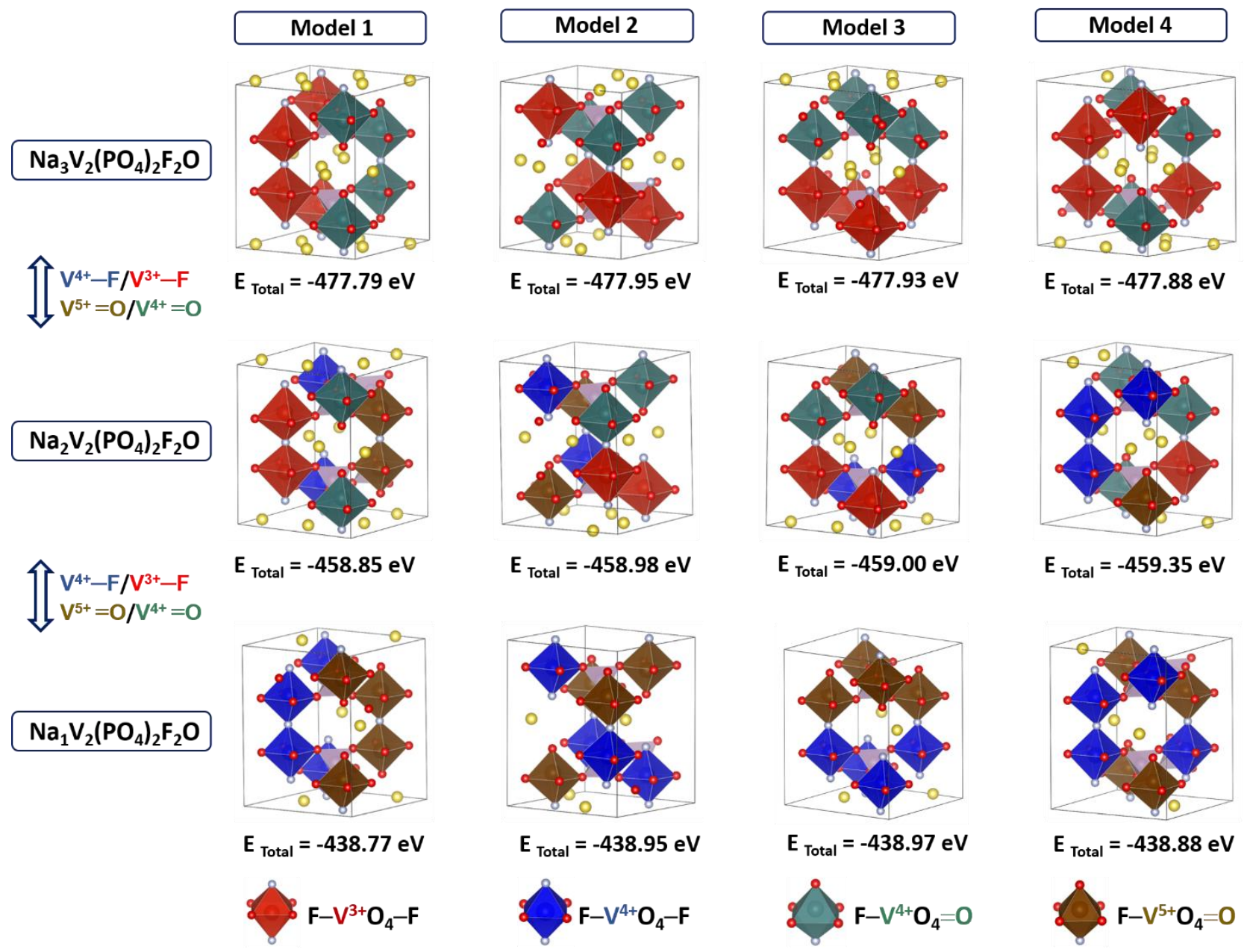

Figure 7. The total energy and the charge distribution on vanadium sites obtained after the structural optimization step within the GGA $+U$ $(U=3.1 \mathrm{eV})$ method for each model at the $\mathrm{Na}_{3} \mathrm{~V}_{2}\left(\mathrm{PO}_{4}\right)_{2} \mathrm{~F}_{2} \mathrm{O}, \mathrm{Na}_{2} \mathrm{~V}_{2}\left(\mathrm{PO}_{4}\right)_{2} \mathrm{~F}_{2} \mathrm{O}$ and $\mathrm{NaV}_{2}\left(\mathrm{PO}_{4}\right)_{2} \mathrm{~F}_{2} \mathrm{O}$ compositions. The redox couples activated when moving from one composition to another are indicated by double-headed arrows on the left panel. $\mathrm{Na}^{+}$ions are represented by yellow spheres and $\mathrm{PO}_{4}$ groups are represented by light purple tetrahedra.

Fourier transformation was performed on the XANES spectra of the three principal components and these components correspond to the charge ordering on vanadium sites where the vanadium oxidation only occurs in pairs. The first component is indeed that of the pristine material where $\mathrm{F}-\mathrm{V}^{3+} \mathrm{O}_{4}-\mathrm{F}$ and $\mathrm{F}-\mathrm{V}^{4+} \mathrm{O}_{4}=\mathrm{O}$ environments co-exist in the $1 / 1$ ratio, and the corresponding EXAFS data were fit by using the [6] $+[4+1+1]$ model as explained earlier.

The DFT results reveal that in the second component, four different vanadium sub-units can co-exist: $\mathrm{F}-\mathrm{O}_{4} \mathrm{~V}^{3+}-\mathrm{F}$, $\mathrm{F}-\mathrm{O}_{4} \mathrm{~V}^{4+}-\mathrm{F}, \mathrm{F}-\mathrm{V}^{4+} \mathrm{O}_{4}=\mathrm{O}$ and $\mathrm{F}-\mathrm{V}^{5+} \mathrm{O}_{4}=\mathrm{O}$, which leads to a necessary use of 24 bond length distances for the EXAFS fit. In order to reduce the number of refined parameters, the $\mathrm{F}-\mathrm{O}_{4} \mathrm{~V}^{3+}-\mathrm{F}$ and $\mathrm{F}-\mathrm{O}_{4} \mathrm{~V}^{4+}-\mathrm{F}$ sites are described together by a single average environment [6] since they are both quasi-symmetric octahedral sites, whereas $\mathrm{F}-\mathrm{V}^{4+} \mathrm{O}_{4}=\mathrm{O}$ and $\mathrm{F}-\mathrm{V}^{5+} \mathrm{O}_{4}=\mathrm{O}$ sites are also described together by a single average environment $[4+1+1]$ as they are both distorted octahedra. The global fitting model is thus depicted as [6] $+[4+1+1]$. The four bond lengths determined from the analyses of the EXAFS data are thus an average description of the symmetric $\mathrm{F}-\mathrm{O}_{4} \mathrm{~V}^{3+}-\mathrm{F} / \mathrm{F}-\mathrm{O}_{4} \mathrm{~V}^{4+}-\mathrm{F}$ environments and the distorted $\mathrm{F}-\mathrm{V}^{4+} \mathrm{O}_{4}=\mathrm{O} / \mathrm{F}-\mathrm{V}^{5+} \mathrm{O}_{4}=\mathrm{O}$ environments. In the final state, the
$\mathrm{F}-\mathrm{O}_{4} \mathrm{~V}^{4+}-\mathrm{F}$ and $\mathrm{F}-\mathrm{V}^{5+} \mathrm{O}_{4}=\mathrm{O}$ sub-octahedra are found in the ratio $1 / 1$ and thus the $[6]+[4+1+1]$ model is retained. Note that all the bioctahedra were broken down into their corresponding sub-units in the EXAFS fit in order to simplify the fitting model. The quality of the EXAFS fit in the R-space and in the $k$-space of the three identified components describing the $\mathrm{Na}_{3} \mathrm{~V}_{2}\left(\mathrm{PO}_{4}\right)_{2} \mathrm{~F}_{2} \mathrm{O}-\mathrm{NaV}_{2}\left(\mathrm{PO}_{4}\right)_{2} \mathrm{~F}_{2} \mathrm{O}$ system are given in Figure $6 \mathrm{~d}$ and Figure $\mathrm{S} 11$. The $\mathrm{V}-\mathrm{O} / \mathrm{F}$ bond lengths obtained from the EXAFS fit are summarized in Figure 3 and Table S2. A short bond length is always detected in the $[4+1+1]$ environment corresponding to the highly covalent vanadyl bond in the $\mathrm{F}-\mathrm{VO}_{4}=\mathrm{O}$ sub-unit. Upon charge, all $\mathrm{V}-\mathrm{F} / \mathrm{O}$ bond lengths are significantly shortened, which is in agreement with a continuous increase in vanadium's oxidation state.

The $\mathrm{Na}_{3} \mathrm{~V}_{2}\left(\mathrm{PO}_{4}\right)_{2} \mathrm{~F}_{1.5} \mathrm{O}_{1.5}-\mathrm{NaV}_{2}\left(\mathrm{PO}_{4}\right)_{2} \mathrm{~F}_{1.5} \mathrm{O}_{1.5}$ System. In the initial state, the symmetric $\mathrm{F}-\mathrm{O}_{4} \mathrm{~V}^{3+}-\mathrm{F}$ and the distorted $\mathrm{F}-\mathrm{V}^{4+} \mathrm{O}_{4}=\mathrm{O}$ sub-units co-exist in a $1 / 3$ ratio, and thus the EXAFS data of this composition was analyzed by using the $25 \% \times[6]+75 \% \times[4+1+1]$ fitting model. Mathematically, one can imagine that one octahedral sub-unit in the bioctahedron is formed purely from $\mathrm{F}-\mathrm{V}^{4+} \mathrm{O}_{4}=\mathrm{O}$ while the other is the $1 / 1$ combination of $\mathrm{F}-\mathrm{O}_{4} \mathrm{~V}^{3+}-\mathrm{F}$ and $\mathrm{F}-\mathrm{V}^{4+} \mathrm{O}_{4}=\mathrm{O}$ (Figure 3 and Table S3). Upon charge, a linear evolution of the operando $\mathrm{V}$ K-edge XANES spectra was observed in the pre-edge and edge 
regions (Figure S12 and Figure S13), and thus indicating a simultaneous activation of $\mathrm{V}^{4+}-\mathrm{F} / \mathrm{V}^{3+}-\mathrm{F}$ and $\left\{\mathrm{V}^{5+}=\mathrm{O}\right\}^{3+} /\left\{\mathrm{V}^{4+}=\mathrm{O}\right\}^{2+}$ redox couples. The PCA analysis reveals the presence of three principal components (Figure S14), whose concentration profiles follow the same trend as those reported for the $\mathrm{Na}_{3} \mathrm{~V}_{2}\left(\mathrm{PO}_{4}\right)_{2} \mathrm{~F}_{2} \mathrm{O}-\mathrm{NaV}_{2}\left(\mathrm{PO}_{4}\right)_{2} \mathrm{~F}_{2} \mathrm{O}$ system (Figure $6 \mathrm{~b}$ and Figure $\mathrm{S} 15 \mathrm{a}$ ), implying a possible charge ordering on vanadium sites in the $\mathrm{Na}_{2} \mathrm{~V}_{2}\left(\mathrm{PO}_{4}\right)_{2} \mathrm{~F}_{1.5} \mathrm{O}_{1.5}$ and $\mathrm{Na}_{2} \mathrm{~V}_{2}\left(\mathrm{PO}_{4}\right)_{2} \mathrm{~F}_{1.5} \mathrm{O}_{1.5}$ compositions. The $\mathrm{V}-\mathrm{O} / \mathrm{F}$ bond lengths of ach principal component obtained from the EXAFS fit using the $25 \% \times[6]+75 \% \times[4+$ $1+1]$ model are given in Figure 3 and Table S3

Complexity of Vanadium Redox Couples. Synchrotron $\mathrm{XAS}$ at V K-edge has long been considered as an advanced technique to probe the vanadium oxidation state and its local environment. Nevertheless, the Nyquist theorem fixes the number of independent parameters that could be refined in the EXFAS analysis, and thus limiting the accuracy and the sensitivity of such technique when heterogeneously distributed local environments are present in the same compound. The vanadium ions in $\mathrm{Na}_{3} \mathrm{~V}_{2}\left(\mathrm{PO}_{4}\right)_{2} \mathrm{~F}_{3}$ related materials form bioctahedral units and, strictly speaking, twelve $\mathrm{V}-\mathrm{O} / \mathrm{F}$ distances would be required to describe one bioctahedron. Upon charge, the vanadium oxidation occurs through a charge ordering process together with the formation of several bioctahedra of different natures and a significant increase in the number of parameters that have to be refined. This situation is beyond the limit of the technique, and thus average structures are required, as illustrated in the above discussions. Even though an average information is obtained, they testify the continuous oxidation of vanadium redox centers in $\mathrm{Na}_{3} \mathrm{~V}_{2}\left(\mathrm{PO}_{4}\right)_{2} \mathrm{~F}_{3-y} \mathrm{O}_{y}$ compositions upon $\mathrm{Na}^{+}$extraction. Furthermore, our results have demystified the redox mechanism of $\mathrm{F}-\mathrm{V}^{4+} \mathrm{O}_{4}=\mathrm{O}$, which had been earlier assigned to the oxidation of the oxygen atom involved in the vanadyl bond. ${ }^{57}$

Further subtle and complex information is revealed if one carefully compares the XANES spectra of $\mathrm{Na}_{3} \mathrm{~V}_{2}\left(\mathrm{PO}_{4}\right)_{2} \mathrm{~F}_{3}$, $\mathrm{Na}_{3} \mathrm{~V}_{2}\left(\mathrm{PO}_{4}\right)_{2} \mathrm{~F}_{2} \mathrm{O}$ and $\mathrm{Na}_{3} \mathrm{~V}_{2}\left(\mathrm{PO}_{4}\right)_{2} \mathrm{~F}_{1.5} \mathrm{O}_{1.5}$ compositions at the initial state and at different stages of charge. In the initial stage, the three materials show evident differences in their edge energy and the intensity of the signal in the pre-edge region (Figure 2). Upon charge, the edge energy of all the phases shifts gradually to a higher value as the oxidation takes place on vanadium centers and the intensity of the signals in the pre-edge region evolves proportionally to the amount of $\mathrm{F}-\mathrm{V}^{5+} \mathrm{O}_{4}=\mathrm{O}$ and $\mathrm{F}-\mathrm{V}^{4+} \mathrm{O}_{4}=\mathrm{O}$ expected at different stages of charge (Figure 8). Interestingly, the edge region of $\mathrm{NaV}_{2}\left(\mathrm{PO}_{4}\right)_{2} \mathrm{~F}_{3}, \mathrm{NaV}_{2}\left(\mathrm{PO}_{4}\right)_{2} \mathrm{~F}_{2} \mathrm{O}$ and $\mathrm{NaV}_{2}\left(\mathrm{PO}_{4}\right)_{2} \mathrm{~F}_{1.5} \mathrm{O}_{1.5}$ can be superimposed perfectly (Figure $8 \mathrm{~b})$ despite the difference in the oxidation state of vanadium ions. This observation demonstrates that at the highly charged state, certain vanadium species with different oxidation states might possess the same absorption energy for the $1 s \rightarrow 4 p$ transition. As a consequence, the conventional identification approach involving the comparison of the edge energy of a compound, containing vanadium ion at an unknown oxidation state, to references, might provoke unexpected errors when dealing with materials at highly charged states. For $\mathrm{Na}_{x} \mathrm{~V}_{2}\left(\mathrm{PO}_{4}\right)_{2} \mathrm{~F}_{3-y} \mathrm{O}_{y}$ $(1 \leq x \leq 3$ and $0 \leq y \leq 2)$ compositions, the pre-edge region contains the signatures of the phase, which should be used for identification purpose.
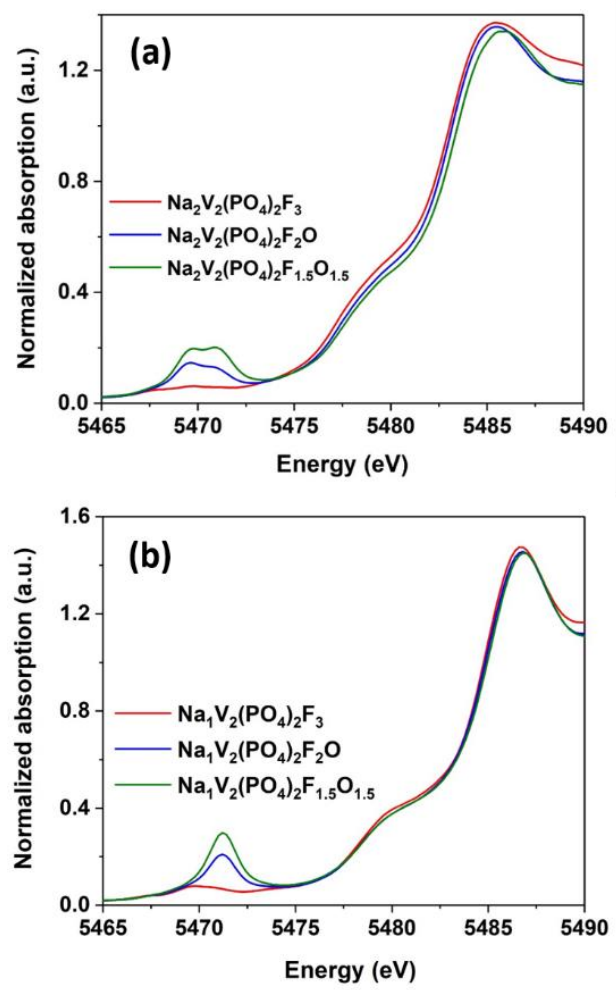

Figure 8. A comparison between the $\mathrm{V}$ K-edge XANES spectra of (a) $\mathrm{Na}_{2} \mathrm{~V}_{2}\left(\mathrm{PO}_{4}\right)_{2} \mathrm{~F}_{3}, \mathrm{Na}_{2} \mathrm{~V}_{2}\left(\mathrm{PO}_{4}\right)_{2} \mathrm{~F}_{2} \mathrm{O}$ and $\mathrm{Na}_{2} \mathrm{~V}_{2}\left(\mathrm{PO}_{4}\right)_{2} \mathrm{~F}_{1.5} \mathrm{O}_{1.5}$, and (b) $\mathrm{NaV}_{2}\left(\mathrm{PO}_{4}\right)_{2} \mathrm{~F}_{3}, \mathrm{NaV}_{2}\left(\mathrm{PO}_{4}\right)_{2} \mathrm{~F}_{2} \mathrm{O}$ and $\mathrm{NaV}_{2}\left(\mathrm{PO}_{4}\right)_{2} \mathrm{~F}_{1.5} \mathrm{O}_{1.5}$.

\section{- CONCLUSIONS}

The redox mechanism upon electrochemical $\mathrm{Na}^{+}$extraction from three different materials, $\mathrm{Na}_{3} \mathrm{~V}_{2}\left(\mathrm{PO}_{4}\right)_{2} \mathrm{~F}_{3}$, $\mathrm{Na}_{3} \mathrm{~V}_{2}\left(\mathrm{PO}_{4}\right)_{2} \mathrm{~F}_{2} \mathrm{O}$, and $\mathrm{Na}_{3} \mathrm{~V}_{2}\left(\mathrm{PO}_{4}\right)_{2} \mathrm{~F}_{1.5} \mathrm{O}_{1.5}$, were investigated by operando synchrotron XAS at Vanadium K-edge. The absorption edge energy and the pre-edge signal observed in these compositions evolved continuously upon charge, implying a direct participation of vanadium redox centers into the redox reactions. Through a systematic comparison, we have illustrated that the evolution of the edge energy in these vanadium-containing materials is rather complex, and particularly, at highly charged state, in which the vanadium ions possessing different oxidation states might exhibit the same absorption energy for the $1 s \rightarrow 4 p$ transition. The vanadium ions in these compounds are found in bioctahedral units and at least twelve parameters would be required to describe all the distances, and thus the EXAFS analysis can only provide the average information on the vanadium local environment. Nonetheless, the 'average' vanadium local environment of the principal components evolved gradually upon charge, which is in agreement with the activation of vanadium redox couples. By the use of DFT calculations combined with chemometric analysis performed on the operando synchrotron XAS at Vanadium K-edge, we have demonstrated that the potential jump observed in all $\mathrm{Na}_{2} \mathrm{~V}_{2}\left(\mathrm{PO}_{4}\right)_{2} \mathrm{~F}_{3-y} \mathrm{O}_{y}$ compositions is due to the formation of charge ordering on vanadium bioctahedra and the vanadium oxidation occurs preferentially on vanadium sites in the same bioctahedra. In $\mathrm{Na}_{3} \mathrm{~V}_{2}\left(\mathrm{PO}_{4}\right)_{2} \mathrm{~F}_{3-y} \mathrm{O}_{y}(0<y<2)$ compositions, the $\mathrm{F}-\mathrm{O}_{4} \mathrm{~V}^{3+}-\mathrm{F}$ and $\mathrm{F}-\mathrm{V}^{4+} \mathrm{O}_{4}=\mathrm{O}$ redox centers indeed coexist and 
they can be simultaneously activated through the reverse inductive effect resulted from the formation of highly covalent vanadyl bonds on $\mathrm{V}^{4+}$ sites.

\section{- AUTHOR INFORMATION}

\section{Corresponding Author}

* L. Croguennec (Laurence.Croguennec@icmcb.cnrs.fr)

\section{ORCID}

Long H.B. Nguyen: 0000-0001-7823-1595

Antonella Iadecola: 0000-0002-9031-8455

Jacob Olchowka: 0000-0001-7430-0266

Christian Masquelier: 0000-0001-7289-1015

Dany Carlier: 0000-0002-5086-4363

Laurence Croguennec: 0000-0002-3018-0992

\section{Author Contributions}

The manuscript was written through contributions of all authors. All authors have given approval to the final version of the manuscript.

\section{Notes}

The authors declare no competing financial interests.

\section{- ASSOCIATED CONTENT}

Supporting Information.

The Supporting Information is available free of charge via the Internet at http://pubs.acs.org.

Definition of reverse inductive effect (Figure S1); Evolution in the edge energy during the cycling of $\mathrm{Na}_{3} \mathrm{~V}_{2}\left(\mathrm{PO}_{4}\right)_{2} \mathrm{~F}_{3}$, $\mathrm{Na}_{3} \mathrm{~V}_{2}\left(\mathrm{PO}_{4}\right)_{2} \mathrm{~F}_{2} \mathrm{O}$, and $\mathrm{Na}_{3} \mathrm{~V}_{2}\left(\mathrm{PO}_{4}\right)_{2} \mathrm{~F}_{1.5} \mathrm{O}_{1.5}$ (Figure $\mathrm{S} 2$, Figure $\mathrm{S} 7$, and Figure S12); Spin distribution map calculated for $\mathrm{Na}_{2} \mathrm{~V}_{2}\left(\mathrm{PO}_{4}\right)_{2} \mathrm{~F}_{3}$ using GGA $+U$ approach (Figure S3); Charge ordering on vanadium sites in $\mathrm{Na}_{2} \mathrm{~V}_{2}\left(\mathrm{PO}_{4}\right)_{2} \mathrm{~F}_{3}$ and $\mathrm{NaV}_{2}\left(\mathrm{PO}_{4}\right)_{2} \mathrm{~F}_{3}$ calculated by $\mathrm{GGA}+U$ approach (Figure $\mathrm{S} 4$ ); Supercell input model for $\mathrm{NaV}_{2}\left(\mathrm{PO}_{4}\right)_{2} \mathrm{~F}_{3}$ (Figure S6); Quality of the EXAFS fit performed on the reconstructed spectra of the principal components observed in the $\mathrm{Na}_{3} \mathrm{~V}_{2}\left(\mathrm{PO}_{4}\right)_{2} \mathrm{~F}_{3}-\mathrm{NaV}_{2}\left(\mathrm{PO}_{4}\right)_{2} \mathrm{~F}_{3}, \quad \mathrm{Na}_{3} \mathrm{~V}_{2}\left(\mathrm{PO}_{4}\right)_{2} \mathrm{~F}_{2} \mathrm{O}$ $-\mathrm{NaV}_{2}\left(\mathrm{PO}_{4}\right)_{2} \mathrm{~F}_{2} \mathrm{O}, \quad$ and $\quad \mathrm{Na}_{3} \mathrm{~V}_{2}\left(\mathrm{PO}_{4}\right)_{2} \mathrm{~F}_{1.5} \mathrm{O}_{1.5}$ $-\mathrm{NaV}_{2}\left(\mathrm{PO}_{4}\right)_{2} \mathrm{~F}_{1.5} \mathrm{O}_{1.5}$ systems (Figure S5, Figure S11, and Figure S15); Example of a fit in the pre-edge area (Figure S8); Evolution in the relative area of the pre-edge observed during the cycling of $\mathrm{Na}_{3} \mathrm{~V}_{2}\left(\mathrm{PO}_{4}\right)_{2} \mathrm{~F}_{2} \mathrm{O}$ and $\mathrm{Na}_{3} \mathrm{~V}_{2}\left(\mathrm{PO}_{4}\right)_{2} \mathrm{~F}_{1.5} \mathrm{O}_{1.5}$ (Figure S9 and Figure S13); Variance plot of the PCA analysis performed on the operando dataset recorded for $\mathrm{Na}_{3} \mathrm{~V}_{2}\left(\mathrm{PO}_{4}\right)_{2} \mathrm{~F}_{2} \mathrm{O}$ and $\mathrm{Na}_{3} \mathrm{~V}_{2}\left(\mathrm{PO}_{4}\right)_{2} \mathrm{~F}_{1.5} \mathrm{O}_{1.5}$ (Figure $\mathrm{S} 10$ and Figure S14); V-F/O distances obtained from the EXAFS analysis performed on the reconstructed spectra of the principal components (Table S1, Table S2, and Table S3).

\section{- ACKNOWLEDGMENT}

The authors thank the RS2E Network for the funding of LHBN's PhD thesis as well as the financial support of Région Nouvelle Aquitaine, of the French National Research Agency (STORE-EX Labex Project ANR-10-LABX-76-01) and of the European Union's Horizon 2020 research and innovation program under the Grant Agreement No. 646433-NAIADES. XAS experiments were performed on the ROCK beamline at SOLEIL synchrotron, which is benefiting from a public grant overseen by the French National Research Agency as part of the "Investissements d'Avenir" program (Reference: ANR-10-EQPX-45). The Mésocentre de Calcul Intensif Aquitain (MCIA) and the modeling center of ISM are acknowledged for computing facilities.

\section{- REFERENCES}

(1) Palomares, V.; Serras, P.; Villaluenga, I.; Hueso, K. B.; CarreteroGonzález, J.; Rojo, T. Na-Ion Batteries, Recent Advances and Present Challenges to Become Low Cost Energy Storage Systems. Energy Environ. Sci. 2012, 5 (3), 5884-5901.

(2) Choi, J. W.; Aurbach, D. Promise and Reality of Post-Lithium-Ion Batteries with High Energy Densities. Nat. Rev. Mater. 2016, 1.

(3) Slater, M. D.; Kim, D.; Lee, E.; Johnson, C. S. Sodium-Ion Batteries. Adv. Funct. Mater. 2013, 23 (8), 947-958.

(4) Kim, S. W.; Seo, D. H.; Ma, X.; Ceder, G.; Kang, K. Electrode Materials for Rechargeable Sodium-Ion Batteries: Potential Alternatives to Current Lithium-Ion Batteries. Adv. Energy Mater. 2012, 2 (7), 710-721.

(5) Delmas, C. Sodium and Sodium-Ion Batteries: 50 Years of Research. Adv. Energy Mater. 2018, 8 (17), 1-9.

(6) Yabuuchi, N.; Kubota, K.; Dahbi, M.; Komaba, S. Research Development on Sodium-Ion Batteries. Chem. Rev. 2014, 114 (23), 1163611682.

(7) Han, M. H.; Gonzalo, E.; Singh, G.; Rojo, T. A Comprehensive Review of Sodium Layered Oxides: Powerful Cathodes for Na-Ion Batteries. Energy Environ. Sci. 2015, 8 (1), 81-102.

(8) Delmas, C.; Braconnier, J.-J.; Fouassier, C.; Hagenmuller, P. Electrochemical Intercalation of Sodium in $\mathrm{Na}_{x} \mathrm{CO}_{2}$ Bronzes. Solid State Ionics 1981, 3-4, 165-169.

(9) Sharma, L.; Nakamoto, K.; Sakamoto, R.; Okada, S.; Barpanda, P. $\mathrm{Na}_{2} \mathrm{FePO}_{4} \mathrm{~F}$ Fluorophosphate as Positive Insertion Material for Aqueous Sodium-Ion Batteries. ChemElectroChem 2019, 6 (2), 444-449.

(10) Ling, R.; Cai, S.; Shen, S.; Hu, X.; Xie, D.; Zhang, F.; Sun, X.; Yu, N.; Wang, F. Synthesis of Carbon Coated $\mathrm{Na}_{2} \mathrm{FePO}_{4} \mathrm{~F}$ as Cathode Materials for High-Performance Sodium Ion Batteries. J. Alloys Compd. 2017, 704, 631 640.

(11) Chen, F.; Kovrugin, V. M.; David, R.; Mentré, O.; Fauth, F.; Chotard, J.; Masquelier, C. A NASICON-Type Positive Electrode for Na Batteries with High Energy Density: $\mathrm{Na}_{4} \mathrm{MnV}\left(\mathrm{PO}_{4}\right)_{3}$. Small Methods 2018, 1800218, 1800218 .

(12) Abakumov, A. M.; Zakharkin, M. V.; Drozhzhin, O. A.; Antipov, E. V.; Chernyshov, D.; Tereshchenko, I. V.; Stevenson, K. J. Enhancing $\mathrm{Na}^{+}$ Extraction Limit through High Voltage Activation of the NASICON-Type $\mathrm{Na}_{4} \mathrm{MnV}\left(\mathrm{PO}_{4}\right)_{3}$ Cathode. ACS Appl. Energy Mater. 2018, 1 (11), 5842 5846.

(13) Park, Y. U.; Seo, D. H.; Kim, H.; Kim, J.; Lee, S.; Kim, B.; Kang, K. A Family of High-Performance Cathode Materials for Na-Ion Batteries, $\mathrm{Na}_{3}\left(\mathrm{VO}_{1-x} \mathrm{PO}_{4}\right)_{2} \mathrm{~F}_{1+2 x} \quad(0 \leq x \leq 1)$ : Combined First-Principles and Experimental Study. Adv. Funct. Mater. 2014, 24 (29), 4603-4614.

(14) Broux, T.; Fauth, F.; Hall, N.; Chatillon, Y.; Bianchini, M.; Bamine, T.; Leriche, J. B.; Suard, E.; Carlier, D.; Reynier, Y.; et al. High Rate Performance for Carbon-Coated $\mathrm{Na}_{3} \mathrm{~V}_{2}\left(\mathrm{PO}_{4}\right)_{2} \mathrm{~F}_{3}$ in Na-Ion Batteries. Small Methods 2019, 3 (4), 1800215.

(15) Guo, J.-Z.; Wang, P.-F.; Wu, X.-L.; Zhang, X.-H.; Yan, Q.; Chen, H.; Zhang, J.-P.; Guo, Y.-G. High-Energy/Power and Low-Temperature Cathode for Sodium-Ion Batteries: In Situ XRD Study and Superior FullCell Performance. Adv. Mater. 2017, 29 (33), 1701968.

(16) Broux, T.; Bamine, T.; Fauth, F.; Simonelli, L.; Olszewski, W.; Marini, C.; Ménétrier, M.; Carlier, D.; Masquelier, C.; Croguennec, L. Strong Impact of the Oxygen Content in $\mathrm{Na}_{3} \mathrm{~V}_{2}\left(\mathrm{PO}_{4}\right)_{2} \mathrm{~F}_{3-y} \mathrm{O}_{y}(0 \leq y \leq 0.5)$ on Its Structural and Electrochemical Properties. Chem. Mater. 2016, 28 (21), 7683-7692.

(17) Serras, P.; Palomares, V.; Goñi, A.; Gil de Muro, I.; Kubiak, P.; Lezama, L.; Rojo, T. High Voltage Cathode Materials for Na-Ion Batteries of General Formula $\mathrm{Na}_{3} \mathrm{~V}_{2} \mathrm{O}_{2 x}\left(\mathrm{PO}_{4}\right)_{2} \mathrm{~F}_{3-2 x}$. J. Mater. Chem. 2012, 22 (41), 22301.

(18) Nguyen, L. H. B.; Broux, T.; Camacho, P. S.; Denux, D.; Bourgeois, L.; Belin, S.; Iadecola, A.; Fauth, F.; Carlier, D.; Olchowka, J.; et al. Stability in Water and Electrochemical Properties of the $\mathrm{Na}_{3} \mathrm{~V}_{2}\left(\mathrm{PO}_{4}\right)_{2} \mathrm{~F}_{3}$ $\mathrm{Na}_{3}(\mathrm{VO})_{2}\left(\mathrm{PO}_{4}\right)_{2} \mathrm{~F}$ Solid Solution. Energy Storage Mater. 2019, 20, 324334

(19) Bianchini, M.; Brisset, N.; Fauth, F.; Weill, F.; Elkaim, E.; Suard, E.; Masquelier, C.; Croguennec, L. $\mathrm{Na}_{3} \mathrm{~V}_{2}\left(\mathrm{PO}_{4}\right)_{2} \mathrm{~F}_{3}$ Revisited: A HighResolution Diffraction Study. Chem. Mater. 2014, 26 (14), 4238-4247. 
(20) Le Meins, J.-M.; Crosnier-Lopez, M.-P.; Hemon-Ribaud, A.; Courbion, G. Phase Transitions in the $\mathrm{Na}_{3} \mathrm{M}_{2}\left(\mathrm{PO}_{4}\right)_{2} \mathrm{~F}_{3}$ Family $\left(\mathrm{M}=\mathrm{Al}^{3+}\right.$, $\left.\mathrm{V}^{3+}, \mathrm{Cr}^{3+}, \mathrm{Fe}^{3+}, \mathrm{Ga}^{3+}\right)$ : Synthesis, Thermal, Structural, and Magnetic Studies. J. Solid State Chem. 1999, 148, 260-277.

(21) Broux, T.; Fleutot, B.; David, R.; Brüll, A.; Veber, P.; Fauth, F.; Courty, M.; Croguennec, L.; Masquelier, C. Temperature Dependence of Structural and Transport Properties for $\mathrm{Na}_{3} \mathrm{~V}_{2}\left(\mathrm{PO}_{4}\right)_{2} \mathrm{~F}_{3}$ and $\mathrm{Na}_{3} \mathrm{~V}_{2}\left(\mathrm{PO}_{4}\right)_{2} \mathrm{~F}_{2.5} \mathrm{O}_{0.5}$. Chem. Mater. 2018, 30 (2), 358-365.

(22) Olchowka, J.; Nguyen, L. H. B.; Broux, T.; Sanz Camacho, P.; Petit, E.; Fauth, F.; Carlier, D.; Masquelier, C.; Croguennec, L. Aluminum Substitution for Vanadium in the $\mathrm{Na}_{3} \mathrm{~V}_{2}\left(\mathrm{PO}_{4}\right)_{2} \mathrm{~F}_{3}$ and $\mathrm{Na}_{3} \mathrm{~V}_{2}\left(\mathrm{PO}_{4}\right)_{2} \mathrm{FO}_{2}$ Type Materials. Chem. Commun. 2019, 55 (78), 11719-11722.

(23) Boivin, E.; Iadecola, A.; Fauth, F.; Chotard, J.-N.; Masquelier, C.; Croguennec, L. Redox Paradox of Vanadium in Tavorite $\mathrm{LiVPO}_{4} \mathrm{~F}_{1-y} \mathrm{O}_{y}$. Chem. Mater. 2019, 31 (18), 7367-7376.

(24) Boivin, E.; Chotard, J.-N.; Ménétrier, M.; Bourgeois, L.; Bamine, T.; Carlier, D.; Fauth, F.; Masquelier, C.; Croguennec, L. Oxidation under Air of Tavorite $\mathrm{LiVPO}_{4} \mathrm{~F}$ : Influence of Vanadyl-Type Defects on Its Electrochemical Properties. J. Phys. Chem. C 2016, 120 (46), 2618726198.

(25) Broux, T.; Bamine, T.; Simonelli, L.; Stievano, L.; Fauth, F.; Ménétrier, M.; Carlier, D.; Masquelier, C.; Croguennec, L. V VIV Disproportionation Upon Sodium Extraction From $\mathrm{Na}_{3} \mathrm{~V}_{2}\left(\mathrm{PO}_{4}\right)_{2} \mathrm{~F}_{3}$ Observed by Operando X-Ray Absorption Spectroscopy and Solid-State NMR. J. Phys. Chem. C 2017, 121 (8), 4103-4111.

(26) Bianchini, M.; Xiao, P.; Wang, Y.; Ceder, G. Additional Sodium Insertion into Polyanionic Cathodes for Higher-Energy Na-Ion Batteries. Adv. Energy Mater. 2017, 7 (18), 1700514.

(27) Li, C.; Shen, M.; Lou, X.; Hu, B. Unraveling the Redox Couples of $\mathrm{V}^{\mathrm{III} / \mathrm{VIV}}$ Mixed-Valent $\mathrm{Na}_{3} \mathrm{~V}_{2}\left(\mathrm{PO}_{4}\right)_{2} \mathrm{O}_{16} \mathrm{~F}_{14}$ Cathode by Parallel-Mode EPR and In Situ/Ex Situ NMR. J. Phys. Chem. C 2018, 122, 27224-27232.

(28) Briois, V.; La Fontaine, C.; Belin, S.; Barthe, L.; Moreno, T.; Pinty, V.; Carcy, A.; Girardot, R.; Fonda, E. ROCK: The New Quick-EXAFS Beamline at SOLEIL. J. Phys. Conf. Ser. 2016, 712 (1).

(29) Leriche, J. B.; Hamelet, S.; Shu, J.; Morcrette, M.; Masquelier, C.; Ouvrard, G.; Zerrouki, M.; Soudan, P.; Belin, S.; Elkä̈m, E.; et al. An Electrochemical Cell for Operando Study of Lithium Batteries Using Synchrotron Radiation. J. Electrochem. Soc. 2010, 157 (5), A606.

(30) Fonda, E.; Rochet, A.; Ribbens, M.; Barthe, L.; Belin, S.; Briois, V. The SAMBA Quick-EXAFS Monochromator: XAS with Edge Jumping. $J$ Synchrotron Radiat. 2012, 19 (3), 417-424.

(31) Lesage, C.; Devers, E.; Legens, C.; Fernandes, G.; Roudenko, O.; Briois, V. High Pressure Cell for Edge Jumping X-Ray Absorption Spectroscopy: Applications to Industrial Liquid Sulfidation of Hydrotreatment Catalysts. Catal. Today 2019, 336, 63-73.

(32) Jaumot, J.; de Juan, A.; Tauler, R. MCR-ALS GUI 2.0: New Features and Applications. Chemom. Intell. Lab. Syst. 2015, 140, 1-12.

(33) Fehse, M.; Iadecola, A.; Sougrati, M. T.; Conti, P.; Giorgetti, M.; Stievano, L. Applying Chemometrics to Study Battery Materials: Towards the Comprehensive Analysis of Complex Operando Datasets. Energy Storage Mater. 2019, 18 (January), 328-337.

(34) Darwiche, A.; Murgia, F.; Fehse, M.; Mahmoud, A.; Iadecola, A.; Belin, S.; La Fontaine, C.; Briois, V.; Hermann, R. P.; Fraisse, B.; et al. Operando X-Ray Absorption Spectroscopy Applied to Battery Materials at ICGM: The Challenging Case of BiSb's Sodiation. Energy Storage Mater. 2019, 21 (January), 1-13.

(35) Nguyen, L. H. B.; Olchowka, J.; Belin, S.; Sanz Camacho, P.; Duttine, M.; Iadecola, A.; Fauth, F.; Carlier, D.; Masquelier, C.; Croguennec, L. Monitoring the Crystal Structure and the Electrochemical Properties of $\mathrm{Na}_{3}(\mathrm{VO})_{2}\left(\mathrm{PO}_{4}\right)_{2} \mathrm{~F}$ through $\mathrm{Fe}^{3+}$ Substitution. ACS Appl. Mater. Interfaces 2019, 11 (42), 38808-38818.

(36) Tauler, R. Multivariate Curve Resolution Applied to Second Order Data. Chemom. Intell. Lab. Syst. 1995, 30 (1), 133-146.

(37) De Juan, A.; Tauler, R. Chemometrics Applied to Unravel Multicomponent Processes and Mixtures: Revisiting Latest Trends in Multivariate Resolution. Anal. Chim. Acta 2003, 500 (1-2), 195-210.
(38) Ruckebusch, C.; Blanchet, L. Multivariate Curve Resolution: A Review of Advanced and Tailored Applications and Challenges. Anal. Chim. Acta 2013, 765, 28-36.

(39) Jaumot, J.; Gargallo, R.; De Juan, A.; Tauler, R. A Graphical UserFriendly Interface for MCR-ALS: A New Tool for Multivariate Curve Resolution in MATLAB. Chemom. Intell. Lab. Syst. 2005, 76 (1), 101-110. (40) Ravel, B.; Newville, M. ATHENA, ARTEMIS, HEPHAESTUS: Data Analysis for X-Ray Absorption Spectroscopy Using IFEFFIT. $J$. Synchrotron Radiat. 2005, 12 (4), 537-541.

(41) Kresse, G.; Joubert, D. From Ultrasoft Pseudopotentials to the Projector Augmented-Wave Method. Phys. Rev. B 1999, 59 (3), 17581775.

(42) Blöchl, P. E. Projector Augmented-Wave Method. Phys. Rev. B 1994, 50 (24), 17953-17979.

(43) Kresse, G.; Hafner, J. Ab Initio Molecular Dynamics for Liquid Metals. Phys. Rev. B 1993, 47 (1), 558-561.

(44) Kresse, G.; Hafner, J. Ab Initio Molecular-Dynamics Simulation of the Liquid-Metalamorphous- Semiconductor Transition in Germanium. Phys. Rev. B 1994, 49 (20), 14251-14269.

(45) Kresse, G.; Furthmüller, J. Efficiency of Ab-Initio Total Energy Calculations for Metals and Semiconductors Using a Plane-Wave Basis Set. Comput. Mater. Sci. 1996, 6 (1), 15-50.

(46) Kresse, G.; Furthmüller, J. Efficient Iterative Schemes for Ab Initio Total-Energy Calculations Using a Plane-Wave Basis Set. Phys. Rev. B Condens. Matter Mater. Phys. 1996, 54 (16), 11169-11186.

(47) Perdew, J. P.; Burke, K.; Ernzerhof, M. Generalized Gradient Approximation Made Simple. Phys. Rev. Lett. 1996, 77 (18), 3865-3868. (48) Jain, A.; Hautier, G.; Ong, S. P.; Moore, C. J.; Fischer, C. C.; Persson, K. A.; Ceder, G. Formation Enthalpies by Mixing GGA and GGA+U Calculations. Phys. Rev. B 2011, 84 (4), 045115.

(49) Dacek, S. T.; Richards, W. D.; Kitchaev, D. A.; Ceder, G. Structure and Dynamics of Fluorophosphate Na-Ion Battery Cathodes. Chem. Mater. 2016, 28 (15), 5450-5460.

(50) Nguyen, L. H. B.; Sanz Camacho, P.; Broux, T.; Olchowka, J.; Masquelier, C.; Croguennec, L.; Carlier, D. Density Functional TheoryAssisted ${ }^{31} \mathrm{P}$ and ${ }^{23} \mathrm{Na}$ Magic-Angle Spinning Nuclear Magnetic Resonance Study of the $\mathrm{Na}_{3} \mathrm{~V}_{2}\left(\mathrm{PO}_{4}\right)_{2} \mathrm{~F}_{3}-\mathrm{Na}_{3} \mathrm{~V}_{2}\left(\mathrm{PO}_{4}\right)_{2} \mathrm{FO}_{2}$ Solid Solution: Unraveling Its Local and Electronic Structures. Chem. Mater. 2019, 31 (23), 97599768 .

(51) Momma, K.; Izumi, F. VESTA: A Three-Dimensional Visualization System for Electronic and Structural Analysis. J. Appl. Crystallogr. 2008, 41 (3), 653-658

(52) Bunker, G. Introduction to XAFS: A Practical Guide to X-Ray Absorption Fine Structure Spectroscopy; Cambridge University Press, 2010.

(53) Penner-Hahn, J. E. X-Ray Absorption Spectroscopy. In Comprehensive Coordination Chemistry II; Elsevier, 2003; pp 159-186.

(54) Wu, Z. Y.; Xian, D. C.; Hu, T. D.; Xie, Y. N.; Tao, Y.; Natoli, C. R.; Paris, E.; Marcelli, A. Quadrupolar Transitions and Medium-Range-Order Effects in Metal K -Edge x-Ray Absorption Spectra of $3 d$ Transition-Metal Compounds. Phys. Rev. B - Condens. Matter Mater. Phys. 2004, 70 (033104), 1-4

(55) Salem, S. I.; Chang, C. N.; Nash, T. J. Energy Shift and Structure of the K-Absorption Edge of Vanadium in Some Vanadium Compounds. Phys. Rev. B 1978, 18 (10), 5168-5173

(56) Bianchini, M.; Fauth, F.; Brisset, N.; Weill, F.; Suard, E.; Masquelier, C.; Croguennec, L. Comprehensive Investigation of the $\mathrm{Na}_{3} \mathrm{~V}_{2}\left(\mathrm{PO}_{4}\right)_{2} \mathrm{~F}_{3}-\mathrm{NaV}_{2}\left(\mathrm{PO}_{4}\right)_{2} \mathrm{~F}_{3}$ System by Operando High Resolution Synchrotron X-ray Diffraction. Chem. Mater. 2015, 27, 3009-3020.

(57) Xu, M.; Xiao, P.; Stauffer, S.; Song, J.; Henkelman, G.; Goodenough, J. B. Theoretical and Experimental Study of Vanadium-Based Fluorophosphate Cathodes for Rechargeable Batteries. Chem. Mater. 2014, 26 (10), 3089-3097. 